Sabounchei Seyed Javad (Orcid ID: 0000-0001-9000-5304)

\title{
Spectral and crystallography studies of new palladacycle complexes with P,C- and C,C-donor ligands; Application of (OAL16) to optimizing the yield of Mizoroki-Heck reaction
}

Seyyed Javad Sabounchei ${ }^{1}\left|\operatorname{Khadijeh~Badpa~}^{1}\right|$ Ali Hashemi ${ }^{1} \mid$ faezeh moniriyan ${ }^{1} \mid$ Robert W.

Gable $^{2}$

${ }^{1}$ Faculty of Chemistry, Bu-Ali Sina University, Hamedan, 65174, Iran.

${ }^{2}$ School of Chemistry, University of Melbourne, Victoria, 3010, Australia.

*Corresponding author: jsabounchei@yahoo.co.uk (S.J. Sabounchei), Tel.: +98 8138272072.

This is the author manuscript accepted for publication and has undergone full peer review but has not been through the copyediting, typesetting, pagination and proofreading process, which may lead to differences between this version and the Version of Record. Please cite this article as doi: $10.1002 /$ aoc.4882

This article is protected by copyright. All rights reserved. 


\begin{abstract}
The new symmetrical diphosphonium salt $\left[\mathrm{Ph}_{2} \mathrm{P}\left(\mathrm{CH}_{2}\right)_{2} \mathrm{PPh}_{2}\left(\mathrm{CH}_{2} \mathrm{C}(\mathrm{O}) \mathrm{C}_{6} \mathrm{H}_{4} \mathrm{Br}\right)_{2}\right]$ $\mathrm{Br}_{2}(\mathbf{S})$ was synthesized in the reaction of 1,2-bis(diphenylphosphino) ethane (dppe) and related ketone. Further treatment with $\mathrm{NEt}_{3}$ gave the symmetrical $\alpha$-keto stabilized diphosphine ylide $\left[\mathrm{Ph}_{2} \mathrm{P}\left(\mathrm{CH}_{2}\right)_{2} \mathrm{PPh}_{2}\left(\mathrm{CHC}(\mathrm{O}) \mathrm{C}_{6} \mathrm{H}_{4} \mathrm{Br}\right)_{2}\right]\left(\mathbf{Y}^{\mathbf{1}}\right)$. The unsymmetrical $\alpha$-keto stabilized diphosphine ylide $\left[\mathrm{Ph}_{2} \mathrm{P}\left(\mathrm{CH}_{2}\right)_{2} \mathrm{PPh}_{2}\left(\mathrm{CHC}(\mathrm{O}) \mathrm{C}_{6} \mathrm{H}_{4} \mathrm{Br}\right)\right]\left(\mathbf{Y}^{2}\right)$ was synthesized in the reaction of diphosphine in 1:1 ratio with 2.3'-dibromoacetophenone, then treatment with $\mathrm{NEt}_{3}$. The reaction of dibromo (1,5-cyclooctadiene)palladium(II), $\left[\mathrm{PdBr}_{2}(\mathrm{COD})\right]$ with this ligand $\left(\mathbf{Y}^{\mathbf{1}}\right)$ in equimolar ratio gave the new $\mathrm{C}, \mathrm{C}$-chelated $\left[\mathrm{PdBr}_{2}\left(\mathrm{Ph}_{2} \mathrm{P}\left(\mathrm{CH}_{2}\right)_{2} \mathrm{PPh}_{2}\left(\mathrm{C}(\mathrm{H}) \mathrm{C}(\mathrm{O}) \mathrm{C}_{6} \mathrm{H}_{4} \mathrm{Br}\right)_{2}\right)\right](\mathbf{1})$ and with unsymmetrical phosphorus ylide $\left[\mathrm{Ph}_{2} \mathrm{P}\left(\mathrm{CH}_{2}\right)_{2} \mathrm{PPh}_{2} \mathrm{C}(\mathrm{H}) \mathrm{C}(\mathrm{O}) \mathrm{C}_{6} \mathrm{H}_{4} \mathrm{Br}\right] \quad\left(\mathbf{Y}^{2}\right)$ gave the new $\mathrm{P}$, C-chelated palladacycle complex $\left[\mathrm{PdBr}_{2}\left(\mathrm{Ph}_{2} \mathrm{P}\left(\mathrm{CH}_{2}\right)_{2} \mathrm{PPh}_{2} \mathrm{C}(\mathrm{H}) \mathrm{C}(\mathrm{O}) \mathrm{Br}\right)\right]$ (2). These compounds were characterized successfully by FT-IR, NMR $\left({ }^{1} \mathrm{H},{ }^{13} \mathrm{C}\right.$ and $\left.{ }^{31} \mathrm{P}\right)$ spectroscopic methods and the crystal structure of $\mathbf{Y}^{\mathbf{1}}$ and $\mathbf{2}$ were elucidated by single crystal X-ray diffraction. The results indicated that the complex 1 was $\mathrm{C}, \mathrm{C}$-chelated whereas complex $\mathbf{2}$ was P, C-chelated. These air/moisture stable complexes were employed as efficient catalysts for the Mizoroki-Heck crosscoupling reaction of several aryl chlorides, and the Taguchi method was used to optimize the yield of Mizoroki-Heck coupling. The optimum condition was found to be as followed: base; $\mathrm{K}_{2} \mathrm{CO}_{3}$, solvent; DMF and loading of catalyst; $0.005 \mathrm{mmol}$.
\end{abstract}


KEYWORDS: Pd -cyclic complexes; unsymmetrical phosphorus ylide; symmetrical phosphorus ylide; X-ray; Taguchi method.

\section{1 | INTRODUCTION}

Stabilized phosphorus ylides derived from diphosphines are important reagents in organic chemistry, and have shown more useful application in organometallic chemistry due to their ambidentate character as ligands [1-3]. Furthermore, they are valuable key intermediates in metal-mediated organic synthesis $[4,5]$. Also, the basicity or steric properties of the two phosphorus atoms in these phosphorus ylides can be different and may be used to get different coordination modes [6]. The coordination chemistry of $\alpha$-keto stabilized phosphorus ylides is interesting to chemists, because of the different bonding modes upon coordination of ylides to metal [7-10], a) C-coordinated (through the $\mathrm{C} \alpha$ atom), b) O- coordinated (through the $\mathrm{O}$ atom of the carbonyl), c) P- coordinated (through the $\mathrm{P}$ atom of the phosphine group), and d) even situations in which the same ylide shows a combination of bonding modes ( Scheme 1).

\section{SCHEME 1}

Additionally, Pd(II) complexes bearing phosphine groups have been extensively applied as efficient catalysts in some cross-coupling reactions [11-17], specifically, the Mizoroki-Heck 
reaction. The Mizoroki-Heck reaction, has emerged as the most important and reliable method for construction of functionalized olefins, and it can be catalyzed with the $\mathrm{Pd}(\mathrm{II})$ complexes of such phosphorus ylides [18,19]. Palladium complexes (1 and 2) were employed as homogeneous catalysts in C-C coupling reactions. There are many controlling factors such as base, solvent, temperature, time, catalyst $(\mathrm{mol} \%)$, etc. The appropriate selection of conditions for cross coupling reactions can be done with the Taguchi Method. The Taguchi method is generally used for process optimization, because it can noticeably reduce the time and costs associated with achieving optimum conditions [20]. Therefore, some of the possible analytical methods like Taguchi, analysis of variance (ANOVA), and signal-to-noise $(\mathrm{S} / \mathrm{N})$ ratio were used in this work.

In this work we have focused our attention to the synthesis, spectroscopic (IR and NMR) and X-ray structural characterization of these new complexes of phosphorus ylide. Furthermore Pd(II) complex catalyzed Mizoroki-Heck coupling reaction of various aryl chlorides and olefins is reported.

\section{2 | EXPERIMENTAL}

\subsection{Materials and methods}

All synthetic reactions were carried out under dry nitrogen using standard Schlenk techniques. 2-bromo-3'- bromoacetophenone, (1,5-cyclooctadiene) (COD) and 1,2-bis(diphenylphosphino) ethane dppe were purchased from commercial sources and used without further purification. The $\left[\mathrm{PdBr}_{2}(\mathrm{COD})\right]$ complex was prepared according to previously published procedures [21]. Phosphorus ylide $\mathrm{Y}^{2}$ was synthesized and characterized with previously published method [3]. 
Toluene, n-hexane and chloroform were used as reagent grade and dried over $\mathrm{Na} / \mathrm{Benzophenone}$ and $\mathrm{CaCl}_{2}$ subsequently. The ${ }^{1} \mathrm{H},{ }^{13} \mathrm{C}$ and ${ }^{31} \mathrm{P}$ NMR spectra were recorded on $250 \mathrm{MHz}$ Bruker and $90 \mathrm{MHz}$ Jeol spectrometers with $\mathrm{CDCl}_{3}$ as solvent at $25{ }^{\circ} \mathrm{C}$. IR spectra were recorded with KBr pellets using a Shimadzu 435-U04 spectrophotometer in the region of $4000-400 \mathrm{~cm}^{-1}$.

\section{2 | Synthesis of diphosphonium salt}

General procedure: A solution consisting of 1, 2-bis (diphenylphosphino) ethane (0.25 mmol) and ketone $(0.5 \mathrm{mmol})$ in acetone $(5 \mathrm{ml})$ was stirred at room temperature for $24 \mathrm{~h}$. The resulting solution was filtered off and concentrated to $c a .3 \mathrm{ml}$ under reduced pressure and then treated with diethyl ether to precipitate the diphosphonium salt.

\subsubsection{Data for $\left[\mathrm{Ph}_{2} \mathrm{P}\left(\mathrm{CH}_{2}\right)_{2} \mathrm{PPh}_{2}\left(\mathrm{CH}_{2} \mathrm{C}(\mathrm{O}) \mathrm{C}_{6} \mathrm{H}_{4} \mathrm{Br}_{2}\right] \mathrm{Br}_{2}(\mathrm{~S})\right.$}

Yield: $0.051 \mathrm{~g}(85 \%)$, M.p. $212^{\circ} \mathrm{C}$. IR (KBr disk) $v\left(\mathrm{~cm}^{-1}\right): 1669(\mathrm{C}=\mathrm{O}) .{ }^{1} \mathrm{H}$ NMR $\left(\mathrm{CDCl}_{3}\right) \delta_{\mathrm{H}}$ (ppm): 4.04 (br, 4H, $\left.\mathrm{CH}_{2}\right), 6.06$ (br, 2H, PCH2CO); 7.58-8.28 (m, 28H, Ph). ${ }^{31} \mathrm{P}$ NMR $\left(\mathrm{CDCl}_{3}\right)$ $\delta_{\mathrm{P}}(\mathrm{ppm}): 26.76\left(\mathrm{~s}, \mathrm{PCH}_{2}\right) .{ }^{13} \mathrm{C} \mathrm{NMR}\left(\mathrm{CDCl}_{3}\right) \delta_{\mathrm{C}}(\mathrm{ppm}): 15.29\left(\mathrm{~m}, \mathrm{CH}_{2}\right) ; 32.9\left(\mathrm{~m}, \mathrm{PCH}_{2}\right)$; 116.95-137.9 (m, Ph); 191.9 (s, CO).

\section{3 | Synthesis of diphosphine ylide}

This article is protected by copyright. All rights reserved. 
General procedure: The diphosphonium salt was further treated with triethyl amine $(0.5$ $\mathrm{ml}$ ) in dry toluene. The triethylammonium bromide was filtered off. Concentration of the toluene layer to $c a .3 \mathrm{ml}$ and subsequent addition of petroleum ether $(20 \mathrm{ml})$ resulted in the precipitation of diphosphine ylide.

\subsection{1 | Data for $\left[\mathrm{Ph}_{2} \mathrm{P}\left(\mathrm{CH}_{2}\right)_{2} \mathrm{PPh}_{2}\left(\mathrm{CHC}(\mathrm{O}) \mathrm{C}_{6} \mathrm{H}_{4} \mathrm{Br}\right)_{2}\right]\left(\mathbf{Y}^{1}\right)$}

Yield: 0.051 g (85\%), M.p. $212^{\circ}$ C. Anal. Calcd. for $\mathrm{C}_{42} \mathrm{H}_{34} \mathrm{Br}_{2} \mathrm{O}_{2} \mathrm{P}_{2}$ (\%): C, 63.66; H, 4.32 . Found: C, 63.75; H, 4.43. IR (KBr disk) $v\left(\mathrm{~cm}^{-1}\right): 1568(\mathrm{C}=\mathrm{O}) .{ }^{1} \mathrm{H}$ NMR $\left(\mathrm{CDCl}_{3}\right) \delta_{\mathrm{H}}(\mathrm{ppm}): 3.33$ (s, 4H, $\left.\mathrm{CH}_{2}\right) ; 4.24(\mathrm{~m}, 1 \mathrm{H}, \mathrm{PCH}) ; 7.24-8.16(\mathrm{~m}, 28 \mathrm{H}, \mathrm{Ph}) .{ }^{31} \mathrm{P}$ NMR $\left(\mathrm{CDCl}_{3}\right) \delta_{\mathrm{P}}(\mathrm{ppm}): 15.26(\mathrm{~s})$. ${ }^{13} \mathrm{C}$ NMR $\left(\mathrm{CDCl}_{3}\right) \delta_{\mathrm{C}}(\mathrm{ppm}): 18.81\left(\mathrm{~m}, \mathrm{CH}_{2}\right) ; 47.9(\mathrm{~m}, \mathrm{PCH}) ; 122.33-143.17(\mathrm{~m}, \mathrm{Ph}) ; 183.46(\mathrm{~s}$, $\mathrm{CO})$.

\section{4 | Synthesis of Pd complexes}

General procedure: To a dichloromethane solution of $\left[\mathrm{PdBr}_{2}(\mathrm{COD})\right](0.5 \mathrm{mmol}, 5 \mathrm{~mL})$, a solution of ylide $(0.5 \mathrm{mmol})\left(5 \mathrm{~mL}, \mathrm{CH}_{2} \mathrm{Cl}_{2}\right)$ was added. The resulting solution was stirred for 2 $\mathrm{h}$ at room temperature and then concentrated to a $c a .2 \mathrm{ml}$ under reduced pressure and treated with n-hexane $(5 \mathrm{ml})$ to afford a yellow precipitate of the Pd complexes of the desired diphosphine ylide.

\subsection{1 | Data for $\left[\mathrm{PdBr}_{2}\left(\mathrm{Ph}_{2} \mathrm{P}\left(\mathrm{CH}_{2}\right)_{2} \mathrm{PPh}_{2}\left(\mathrm{C}(\mathrm{H}) \mathrm{C}(\mathrm{O}) \mathrm{C}_{6} \mathrm{H}_{4}-m-\mathrm{Br}\right)_{2}\right)\right](1)$.}

Yield: 0.054 g (95\%), M.p. $205^{\circ} \mathrm{C}$. IR (KBr disk) $v\left(\mathrm{~cm}^{-1}\right): 1634(\mathrm{C}=\mathrm{O}) .{ }^{1} \mathrm{H}$ NMR $\left(\mathrm{CDCl}_{3}\right) \delta_{\mathrm{H}}$ (ppm): 3.7 (m, 4H, $\left.\mathrm{PCH}_{2}\right) ; 6.5$ (br, 1H, PCH); 7-8.6 (m, 28H, Ph). ${ }^{31} \mathrm{P} \mathrm{NMR}\left(\mathrm{CDCl}_{3}\right) \delta_{\mathrm{P}}(\mathrm{ppm})$ : 
$29.57\left(\mathrm{~d}, \mathrm{PPh}_{2},{ }^{2} \mathrm{~J}_{\mathrm{P}-\mathrm{P}}=4 \mathrm{~Hz}\right) ; 32.9\left(\mathrm{~d}, \mathrm{PCH},{ }^{2} \mathrm{~J}_{\mathrm{P}-\mathrm{P}}=4 \mathrm{~Hz}\right) .{ }^{13} \mathrm{C} \mathrm{NMR}\left(\mathrm{CDCl}_{3}\right) \delta_{\mathrm{C}}(\mathrm{ppm}): 38.72(\mathrm{~s}$, $\left.\mathrm{CH}_{2}\right) ; 50.81$ (s, $\left.\mathrm{PCH}\right) ; 118.78-140.87$ (m, Ph); 197.99(s, CO).

\subsection{2 | Data for $\left[\mathrm{PdBr}_{2}\left(\mathrm{Ph}_{2} \mathrm{P}\left(\mathrm{CH}_{2}\right)_{2} \mathrm{PPh}_{2} \mathrm{C}(\mathrm{H}) \mathrm{C}(\mathrm{O}) \mathrm{C}_{6} \mathrm{H}_{4}-m-\mathrm{Br}\right)\right]$ (2).}

Yield: 0.051 g (85\%), M.p. $212{ }^{\circ} \mathrm{C}$. Anal. Calcd. for $\mathrm{C}_{34} \mathrm{H}_{29} \mathrm{Br}_{3} \mathrm{OP}_{2} \mathrm{Pd}(\%)$ : C, 52.15; H, 5.53 . Found: C, 52.23; H, 5.64. IR ( $\mathrm{KBr}$ disk) $v\left(\mathrm{~cm}^{-1}\right): 1622(\mathrm{C}=\mathrm{O}) .{ }^{1} \mathrm{H} \mathrm{NMR}\left(\mathrm{CDCl}_{3}\right) \delta_{\mathrm{H}}(\mathrm{ppm}): 4.8$ (m, 4H, $\left.\mathrm{PCH}_{2} \mathrm{P}\right) ; 5.8(\mathrm{~s}, \mathrm{H}, \mathrm{PCH}) ; 7-8.3(\mathrm{~m}, 24 \mathrm{H}, \mathrm{Ph}) .{ }^{31} \mathrm{P}$ NMR $\left(\mathrm{CDCl}_{3}\right) \delta_{\mathrm{P}}(\mathrm{ppm}): 22.54(\mathrm{~d}$ $\left.\mathrm{PPh}_{2},{ }^{2} \mathrm{~J}_{\mathrm{P}-\mathrm{P}}=22.22 \mathrm{~Hz}\right) ; 30.66\left(\mathrm{~d}, \mathrm{PCH},{ }^{2} \mathrm{~J}_{\mathrm{P}-\mathrm{P}}=22.22 \mathrm{~Hz}\right) .{ }^{13} \mathrm{C} \mathrm{NMR}\left(\mathrm{CDCl}_{3}\right) \delta_{\mathrm{C}}(\mathrm{ppm}): 27.94(\mathrm{~s}$, $\left.\mathrm{CH}_{2}\right) ; 49$ (s, PCH); 121.81-140.32 (m, Ph); 194.25(s, CO).

\section{5 | Crystallography}

Single crystals of $\mathbf{Y}^{\mathbf{1}}$ and $\mathbf{2}$ were crystallized by slow evaporation from dichloromethane solution. A suitable crystal was selected and mounted on a Rigaku Oxford Diffraction SuperNova, Dual, $\mathrm{Cu}$ at zero, Atlas diffractometer. The crystal was kept at 130.00(10) K during data collection. Using Olex2 [22], the structure was solved with the ShelXT [23] structure solution program using Intrinsic Phasing and refined with the ShelXL [24] refinement package using Least Squares minimisation. Gaussian absorption corrections were applied to the data. All non-hydrogen atoms were refined with anisotropic displacement parameters, using all data. Hydrogen atoms were located in ideal positions. For 2 there were two independent molecules in the asymmetric unit, together with a molecule of dichloromethane and a partially occupied molecule of solvent water; the occupancy factor refined to $0.368(13)$. 


\section{6 | Typical procedure for the Mizoroki-Heck reaction}

2.6.1 General procedure: Palladium(II) complex 2 (0.005 mmol), olefin $(0.75 \mathrm{mmol})$, aryl chloride $(0.5 \mathrm{mmol}), \mathrm{K}_{2} \mathrm{CO}_{3}(1 \mathrm{mmol})$ and $\mathrm{DMF}(2 \mathrm{~mL})$ were added to a small tube and the mixture was heated to $130{ }^{\circ} \mathrm{C}$ for $6 \mathrm{~h}$ in the presence of air. The reactions were monitored by thin-layer chromatography (TLC). After being cooled to ambient temperature, the mixture was extracted with n-hexane: EtOAc (8:2) filtered and purified by recrystallization from ethanol and water or purified by silica gel column chromatography to give a crude product which was analyzed by ${ }^{1} \mathrm{H}$ and ${ }^{13} \mathrm{C}$ NMR spectroscopy.

2.6.2 Data for $\boldsymbol{p}$-CH $\mathbf{C H}_{3}-\mathbf{P h}-\mathbf{C H}=\mathbf{C H C O O E t}(\mathbf{5 a}) .{ }^{1} \mathrm{H} \mathrm{NMR}\left(\mathrm{CDCl}_{3}\right) \delta_{\mathrm{H}}(\mathrm{ppm}): \delta=7.66(\mathrm{~d}, 1 \mathrm{H}$, CHCO, J = 16.21 Hz), 7.13-7.47 (m, 4H, Ph), $6.38(\mathrm{~d}, 1 \mathrm{H}, \mathrm{CHPh} \mathrm{J}=16.03 \mathrm{~Hz}), 4.26(\mathrm{q}, 2 \mathrm{H}$,

$\left.\mathrm{CH}_{2}, \mathrm{~J}=7.07 \mathrm{~Hz}\right), 2.37\left(\mathrm{~s}, 3 \mathrm{H}, \mathrm{CH}_{3}\right), 1.33\left(\mathrm{t}, 3 \mathrm{H}, \mathrm{CH}_{3} \mathrm{~J}=6.98 \mathrm{~Hz}\right) .{ }^{13} \mathrm{C} \mathrm{NMR}(\mathrm{ppm}): \delta=167.2$ (s, CO), 144.5, 140.6, 131.7, 129.6, 128.0, 117.1, $60.4\left(\mathrm{~s}, \mathrm{CH}_{2}\right), 21.4\left(\mathrm{~s}, \mathrm{CH}_{3}\right), 14.3\left(\mathrm{~s}, \mathrm{CH}_{3}\right)$.

2.6.3 Data for $\boldsymbol{p}$-CHO-Ph-CH=CHCOOEt (5b). ${ }^{1} \mathrm{H}$ NMR $\left(\mathrm{CDCl}_{3}\right) \delta_{\mathrm{H}}(\mathrm{ppm}): 9.95(\mathrm{~s}, 1 \mathrm{H}$, CHCO), 7.35-7.88 (m, 5H, Ph), $6.47(\mathrm{~d}, 1 \mathrm{H}, \mathrm{CHPh}, \mathrm{J}=16.21 \mathrm{~Hz}), 4.23\left(\mathrm{q}, 2 \mathrm{H}, \mathrm{CH}_{2}, \mathrm{~J}=7.25\right.$ $\mathrm{Hz}), 1.28\left(\mathrm{t}, 3 \mathrm{H}, \mathrm{CH}_{3}, \mathrm{~J}=6.98 \mathrm{~Hz}\right) .{ }^{13} \mathrm{C} \mathrm{NMR}(\mathrm{ppm}): \delta=190.4(\mathrm{~s}, \mathrm{CO}), 165.3$ (s, CO), 141.7, 139.0, 136.0, 129.1, 127.4, 120.3, $59.7\left(\mathrm{~s}, \mathrm{CH}_{2}\right), 13.2\left(\mathrm{~s}, \mathrm{CH}_{3}\right)$.

2.6.4 Data for $\boldsymbol{p}$-NO $\mathrm{NO}_{2}$-Ph-CH=CHCOOEt (5c). ${ }^{1} \mathrm{H}$ NMR $\left(\mathrm{CDCl}_{3}\right) \delta_{\mathrm{H}}(\mathrm{ppm}): 7.18-8.22(\mathrm{~m}$, 5H, Ph), 6.47 (d, 1H, CHCO, J = 16.03 Hz), $4.22\left(\mathrm{q}, 2 \mathrm{H}, \mathrm{CH}_{2}, \mathrm{~J}=7.07 \mathrm{~Hz}\right), 1.28\left(\mathrm{t}, 3 \mathrm{H}, \mathrm{CH}_{3}, \mathrm{~J}=\right.$ 
$7.34 \mathrm{~Hz}) .{ }^{13} \mathrm{C}$ NMR (ppm): $\delta=166.7$ (s, CO), 139.5, 137.0, 130.8, 128.3, 128.0, 117.0, 60.4 (s, $\left.\mathrm{CH}_{2}\right), 14.3\left(\mathrm{~s}, \mathrm{CH}_{3}\right)$.

2.6.5 Data for Ph-CH=CHCOOEt (5d). ${ }^{1} \mathrm{H}$ NMR $\left(\mathrm{CDCl}_{3}\right) \delta_{\mathrm{H}}(\mathrm{ppm}): 7.56(\mathrm{~d}, 1 \mathrm{H}, \mathrm{CHCO}, \mathrm{J}=$ $16.10 \mathrm{~Hz}), 7.24-7.65(\mathrm{~m}, 5 \mathrm{H}, \mathrm{Ph}), 6.30(\mathrm{~d}, 1 \mathrm{H}, \mathrm{CHPh}, \mathrm{J}=16.03 \mathrm{~Hz}), 4.13\left(\mathrm{q}, 2 \mathrm{H}, \mathrm{CH}_{2}, \mathrm{~J}=6.98\right.$ $\mathrm{Hz}), 1.20\left(\mathrm{t}, 3 \mathrm{H}, \mathrm{CH}_{3}, \mathrm{~J}=6.98 \mathrm{~Hz}\right) .{ }^{13} \mathrm{C} \mathrm{NMR}(\mathrm{ppm}): \delta=165.8$ (s, CO), 143.4, 133.3, 129.1, $127.8,126.9,117.1,59.3\left(\mathrm{~s}, \mathrm{CH}_{2}\right), 13.2\left(\mathrm{~s}, \mathrm{CH}_{3}\right)$.

2.6.6 | Data for $\boldsymbol{p}$ - $\mathbf{C H}_{3} \mathrm{OC}-\mathbf{P h}-\mathbf{C H}=\mathbf{C H C O O E t}(\mathbf{5 e}) .{ }^{1} \mathrm{H}$ NMR $\left(\mathrm{CDCl}_{3}\right) \delta_{\mathrm{H}}(\mathrm{ppm}): 7.77(\mathrm{~d}, 1 \mathrm{H}$, CHCO, J = 15.68 Hz), 6.99-7.37 (m, 4H, ph), $6.22(\mathrm{~d}, 1 \mathrm{H}, \mathrm{CHPh}, \mathrm{J}=15.77 \mathrm{~Hz}), 4.23(\mathrm{q}, 2 \mathrm{H}$, $\left.\mathrm{CH}_{2}, \mathrm{~J}=7.07 \mathrm{~Hz}\right), 2.56\left(\mathrm{~s}, 3 \mathrm{H}, \mathrm{CH}_{3}\right), 1.31\left(\mathrm{t}, 3 \mathrm{H}, \mathrm{CH}_{3} \mathrm{O}, \mathrm{J}=7.16 \mathrm{~Hz}\right) .{ }^{13} \mathrm{C} \mathrm{NMR}(\mathrm{ppm}): \delta=$ 197.2 (s, CO), 166.7 (s, CO), 138.5, 137.0, 130.8, 128.3, 128.1, 117.0, $60.6\left(\mathrm{~s}, \mathrm{CH}_{2}\right), 14.2$ (s, $\left.\mathrm{CH}_{3}\right)$.

\section{3 | RESULTS AND DISCUSSION}

\section{1 | Synthesis}

Diphosphine $\mathrm{Ph}_{2} \mathrm{P}\left(\mathrm{CH}_{2}\right)_{2} \mathrm{PPh}_{2}$ reacts in 1:2 ratio with 2.3'-dibromoacetophenone forming the new diphosphonium salt $\mathbf{S}$ in $90-95 \%$ yields. Further treatment of this salt with triethyl amine leads to elimination of $\mathrm{HBr}$, giving the new symmetrical diphosphine ylide $\mathbf{Y}^{\mathbf{1}}$ in $80-85 \%$ yields. The reaction of $\left[\operatorname{PdBr}_{2}(\mathrm{COD})\right]$ with this ligand $\left(\mathbf{Y}^{\mathbf{1}}\right)$ in equimolar ratio gave the new C,Cchelated $\left[\mathrm{PdBr}_{2}\left(\mathrm{Ph}_{2} \mathrm{P}\left(\mathrm{CH}_{2}\right)_{2} \mathrm{PPh}_{2}\left(\mathrm{C}(\mathrm{H}) \mathrm{C}(\mathrm{O}) \mathrm{C}_{6} \mathrm{H}_{4} \mathrm{Br}\right)_{2}\right)\right]$ (1) and with the unsymmetrical phosphorus ylide $\left[\mathrm{Ph}_{2} \mathrm{P}\left(\mathrm{CH}_{2}\right)_{2} \mathrm{PPh}_{2} \mathrm{C}(\mathrm{H}) \mathrm{C}(\mathrm{O}) \mathrm{C}_{6} \mathrm{H}_{4} \mathrm{Br}\right]\left(\mathbf{Y}^{2}\right)$ gave the $\mathrm{P}, \mathrm{C}$-chelated palladacycle

This article is protected by copyright. All rights reserved. 
complex $\left[\mathrm{PdBr}_{2}\left(\mathrm{Ph}_{2} \mathrm{P}\left(\mathrm{CH}_{2}\right)_{2} \mathrm{PPh}_{2} \mathrm{C}(\mathrm{H}) \mathrm{C}(\mathrm{O}) \mathrm{Br}\right)\right]$ (2) (Scheme 2). All complexes are moderately soluble in dichloromethane and insoluble in non-polar solvents, such as n-hexane.

\section{SCHEME 2}

\section{2 | Characterization}

The structure of products was characterized by IR, ${ }^{1} \mathrm{H},{ }^{13} \mathrm{C}$ and ${ }^{31} \mathrm{P}$ NMR spectroscopic methods; Table 1 shows important details.

\section{TABLE 1}

\subsection{1 | Infra-red spectra}

The $v(\mathrm{CO})$ in the IR spectra of phosphorus ylide $\mathbf{Y}^{\mathbf{1}}$ was observed in lower frequencies than those of the related phosphonium salt $\mathbf{S}$, suggesting some lowering of electron density in the $\mathrm{C}=\mathrm{O}$ bond. As noted in the literature [25], coordination of ylide through the carbon, causes a significant increase in the $v$ CO frequency. IR spectra of complexes $\mathbf{1}$ and $\mathbf{2}$ show a significantly frequency shift of $v(\mathrm{CO})$ than those of the related phosphorus ylides $\mathbf{Y}^{\mathbf{1}}$ and $\mathbf{Y}^{\mathbf{2}}$. These observations are in agreement with the chelating of ylide $\mathbf{Y}^{\mathbf{1}}$ through two C $\alpha$ atoms and ylide $\mathbf{Y}^{\mathbf{2}}$ through the P and $\mathrm{C} \alpha$ atoms. Presence of $v$ CO bands around $1634-1622 \mathrm{~cm}^{-1}$ in the IR spectra of these complexes indicates that products (C, C and P, C-chelated complexes) were formed.

\subsection{2 | NMR}


The ${ }^{31} \mathrm{P}$ NMR spectra of phosphonium salt $\mathbf{S}$ shows a singlet around $26.76 \mathrm{ppm}$, due to the $\mathrm{PPh}_{2}$ groups, which indicates that the two phosphorus atoms are equivalent, this peak shifted to around 15.26 ppm in spectra of ylide $\mathbf{Y}^{\mathbf{1}}$, and show upfield shift compared to that of parent phosphonium salt, suggesting some electron density increase in the $\mathrm{P}-\mathrm{C}$ bond. The ${ }^{31} \mathrm{P}$ chemical shift values for complexes $\mathbf{1}$ and $\mathbf{2}$ appear to be shifted downfield with respect to parent ylides $\mathbf{Y}^{\mathbf{1}}$ and $\mathbf{Y}^{\mathbf{2}}$, indicating that coordination of the ylide has occurred. Coordination of phosphorus ylides as C, C-chelated and $\mathrm{P}, \mathrm{C}$-chelated forms can make a large chemical shift for both free $\left(\mathrm{PPh}_{2}\right)$ and bonded $(\mathrm{PCH})$ phosphorus atoms. While, in $\mathrm{P}, \mathrm{P}$ - coordinated form only the signal of $\mathrm{PPh}_{2}$ moiety was shifted to higher frequencies. The ${ }^{31} \mathrm{P}$ NMR spectrum of the complex $\mathbf{1}$ features two doublets around 29.57, 32.9 ppm, shifted downfield compared with that of the phosphorus ylide (around $15.26 \mathrm{ppm}$ ), due to the coordination of the ylide to palladium through the carbon atoms (ylidic carbon)[26]. The ${ }^{31} \mathrm{P}$ NMR spectrum of complex 2 shows two doublet peaks around $\delta=22.54,30.66 \mathrm{ppm}$ which are assigned to $\mathrm{PPh}_{2}$ and $\mathrm{PCH}$, respectively.

The ${ }^{1} \mathrm{H}$ NMR spectra of the ylide $\mathbf{Y}^{\mathbf{1}}$ shows an upfield shift in the $\mathrm{CH}$ signals compared to those of the phosphonium salt $\mathbf{S}$. These observations were related to the increasing of the electron density in the P-C bonds. The ${ }^{1} \mathrm{H}$ NMR spectra of complexes $\mathbf{1}$ and $\mathbf{2}$ exhibit characteristic shifts in the methinic proton signals. This is interesting, because complexation of the ylides $\left(\mathbf{Y}^{\mathbf{1}} / \mathbf{Y}^{\mathbf{2}}\right)$ to Pd through free phosphorus atom did not significantly change the chemical shift values of ${ }^{1} \mathrm{H}$ NMR. While, coordination through carbanion causes to shift of $\mathrm{PCH}$ peaks to higher frequency around 6.33- 6.41ppm. The ${ }^{1} \mathrm{H}$ chemical shift values for these complexes 
appeared to be shifted downfield with respect to the parent ylide, indicating also that the coordination of the ylide $\mathbf{Y}^{\mathbf{1}}$ in complex $\mathbf{1}$ has occurred through two C $\alpha$ atoms and in complex $\mathbf{2}$ of the ylide $\mathbf{Y}^{2}$ through $\mathrm{P}$ and $\mathrm{C} \alpha$ atoms.

In the ${ }^{13} \mathrm{C}$ NMR spectra of complexes $\mathbf{1}$ and $\mathbf{2}$, most of the expected resonances are visible and characteristic peaks of carbonyl, methinic and methanediyl groups in complexes $\mathbf{1}$ and 2 show downfield shift respect to the parent ylide $\mathbf{Y}^{\mathbf{1}}$ and $\mathbf{Y}^{\mathbf{2}}$. Furthermore, strong deshielding in resonance value was observed for the $\mathrm{CH}_{2}$ after complexation (around $10 \mathrm{ppm}$ ), which is in agreement with the $\mathrm{C}, \mathrm{C}$ - coordination character of the ylide in complex $\mathbf{1}$. These observations also confirmed that coordination of ylides $\mathbf{Y}^{\mathbf{2}}$ has occurred through $\mathrm{P}$ and $\mathrm{C} \alpha$ atoms and ylide $\mathbf{Y}^{\mathbf{1}}$ has occurred through the two $\mathrm{C} \alpha$ atoms.

\section{3 | Crystallography}

Suitable single crystals of $\mathbf{Y}^{\mathbf{1}}$ and $\mathbf{2}$ were grown by slow evaporation from dichloromethane solution. The molecular structures of $\mathbf{Y}^{\mathbf{1}}$ and $\mathbf{2}$ are shown in Fig. 1 and Fig. 2, respectively. Relevant parameters concerning data collection and refinement are given in Table 2. Selected bond distances and angles for the unit cells of $\mathbf{Y}^{\mathbf{1}}$ and $\mathbf{2}$ are displayed in Table 3.

\section{FIG. 1}

FIG. 2

TABLE 2 


\section{TABLE 3}

\subsubsection{Crystal structures of $\mathbf{Y}^{1}$}

The molecule lies on a center of symmetry. The phosphorous atom is coplanar with the keto group, the dihedral angle between these atoms and the aromatic ring is $21.08(9)^{\circ}$ while the $\mathrm{Br}$ atom on the attached aromatic ring is oriented away from the carbonyl oxygen, the $\mathrm{Br}_{1}-\mathrm{C}_{5} \ldots \mathrm{C}_{2}$ $\mathrm{O}_{1}$ torsion angle being $-154.77(16)^{\circ}$. The structure has some similarities to 2,2'-(ethane-1,2diylbis(diphenylphosphoranylylidene))bis(1-(2,4-dichlorophenyl)ethanone) [12], in particular the observation that the $\mathrm{P}_{1}-\mathrm{C}_{1}$ and $\mathrm{C}_{1}-\mathrm{C}_{2}$ bond lengths are shorter than the normal values found for $\left(\mathrm{P}^{+}-\mathrm{C}\left(\mathrm{sp}^{3}\right)\right)$ and $\left(\mathrm{C}-\mathrm{C}\left(\mathrm{sp}^{3}\right)\right)$ bonds, $1.800 \AA$ and $1.511 \AA$, respectively [39], while the C-O bond length is significantly longer than the normal value of $1.210 \AA$. This has been attributed to the ylidic resonance involving electron delocalization over the $\mathrm{P}_{1}-\mathrm{C}_{1}-\mathrm{C}_{2}-\mathrm{O}_{1}$ moiety $[12,39]$. One main difference between the two structures, however, is that the dihedral angle between the keto group and the attached chlorinated aromatic ring in this latter compound is $59.9^{\circ}$ for molecule $\mathbf{1}$ and $61.9^{\circ}$ for molecule 2 .

The carbonyl oxygen is involved in two weak C-H...O hydrogen bonds, an intramolecular interaction between the carbonyl oxygen and a methylene $\mathrm{H}$-atom, and an intermolecular CH...O interaction that links the molecules into a chain lying along the b-axis. 


\subsection{2 $\mid$ Crystal structures of 2}

There are two crystallographically independent molecules in the asymmetric unit. For molecule 2-1 the Pd is in a slightly tetrahedrally distorted square planar environment, comprising two ciscoordinating $\mathrm{Br}$ atoms, one phosphorous atom and an ylid carbon; the rms deviation of the four

coordinating atoms, for molecule 2-1 is $0.260 \AA$, with $\mathrm{Pd}_{1}$ lying $0.0094(13) \AA$ out of the least squares plane. The keto oxygen is oriented away from the $\mathrm{Pd}$ atom, the torsion angle $\mathrm{Pd}_{1}-\mathrm{C}_{1}-$ $\mathrm{C}_{2}-\mathrm{O}_{1}$ being $99.4(4)^{\circ}$, while the dihedral angle between the bromo-substituted aromatic ring and the keto group is $7.3(4)^{\circ}$. For molecule $\mathbf{2 - 2}$ the distortion from ideal square planar geometry is somewhat greater; the rms deviation of the four coordinating atoms is $0.415 \AA$, with $\mathrm{Pd}_{2}$ lying 0.1697(9) $\AA$ out of the least squares plane. The keto oxygen is oriented away from the Pd atom, the torsion angle $\mathrm{Pd}_{2}-\mathrm{C}_{35}-\mathrm{C}_{36}-\mathrm{O}_{2}$ being $96.9(4)^{\circ}$, while the dihedral angle between the bromosubstituted aromatic ring and the keto group is $23.1(2)^{\circ}$. The main difference between the two molecules is in the conformation of the six-membered palladacycle rings. For molecule 2-1, the ring is in a chair conformation $\left(\mathrm{P}_{1}, \mathrm{C}_{22}, \mathrm{P}_{2}, \mathrm{C}_{1}\right.$ lying in the equatorial plane, with the rms deviation being $0.005 \AA$, and with $\mathrm{Pd}_{1}$ and $\mathrm{C}_{21}$ in the axial positions), while for molecule 2-2, the ring is in a highly distorted boat conformation $\left(\mathrm{Pd}_{2}, \mathrm{P}_{4}, \mathrm{C}_{55}, \mathrm{P}_{3}\right.$ lying in the equatorial plane, with the rms deviation being $0.281 \AA$, and with $\mathrm{C}_{35}$ and $\mathrm{C}_{56}$ in the axial positions).

Both molecules show weak intermolecular and intramolecular and $\mathrm{C}-\mathrm{H} \ldots \mathrm{O}$ and $\mathrm{C}-\mathrm{H} \ldots \mathrm{Br}$ hydrogen bonds, the intermolecular $\mathrm{C}-\mathrm{H} . . . \mathrm{Br}$ hydrogen bonds link the molecules along the $\mathrm{c}$ axis (see fig. 3). 


\section{FIG. 3}

\section{4 | Catalytic activity}

\subsubsection{Optimizition of reaction using Taguchi method}

The catalytic activity of complexes $\mathbf{1}$ and $\mathbf{2}$ in the Mizoroki-Heck coupling reaction of aryl chlorides with ethyl acrylate was examined. The Taguchi method is a statistical approach to optimize the process parameters and can be expanded to improve the performance of total quality control [27] and involves identification of the appropriate control factors to obtain the optimum results of the process. Initially, we set up a systematic optimization of reaction conditions using the Taguchi L16 experimental design. Orthogonal Arrays (OA) are used to conduct a set of experiments. In this work, the orthogonal array (OA), signal-to-noise ratio and the analysis of variance are employed to study the performance characteristics on response [28]. To select an appropriate orthogonal array for conducting the experiments, the degrees of freedom are to be computed. The three selected factors, including the base (B), solvent (S) and catalyst loading (C), were used with their levels (Table 4) [29].

\section{TABLE 4}

The most suitable orthogonal array for experimentation is L16 array as shown in Table 5. Therefore, a total 16 experiments are to be carried out. Whereas, the full factorial experimental design requires $3^{4}=81$ different experiments to evaluate the influencing factors. Results of 
these experiments are used to analyze the data and predict the quality of components produced. Table 5 presents the required experiments to optimize the batch system which were designed using Taguchi method. Initially, we carried out a model reaction to optimize the reaction conditions including solvent, base and catalyst loading. In each run, commonly used bases and solvents, including organic and inorganic bases and polar protic solvents to non-polar aprotic solvents were tested. Also, different amounts of catalyst loadings (mol \%) were used in different temperatures to find optimum reaction conditions. All experiments were repeated, and the yield percentage of reaction was calculated for each experiment [30].

\section{TABLE 5}

We applied the signal-to-noise $(\mathrm{S} / \mathrm{N})$ ratio to evaluate the experimental data, the $\mathrm{S} / \mathrm{N}$ ratio analysis chosen was the larger-the-better [31]. According the values of mean $\mathrm{S} / \mathrm{N}$ ratio is shown in Table 5 and the optimum level of each factor was determined from the highest value of $\mathrm{S} / \mathrm{N}$ ratio revealed in Fig. 4. The optimum condition was found to be base: $\mathrm{K}_{2} \mathrm{CO}_{3}, \mathrm{~K}_{3} \mathrm{PO}_{4}$, solvent: DMF, DMF/Water and catalyst loading (mol \%): 0.005, 0.01.

\section{FIG. 4}

Analysis of variance (ANOVA) is used to evaluate the response magnitude in (\%) of each parameter in the orthogonal experiment. To conclude the optimum conditions for yield of experiments, we used the relationship between each parameter and their percentage contribution $\rho$ and the analysis of variance (ANOVA) [32-34]. F-Statistics also illustrates the significance of each factor on the response quality. 
The contribution percentage of each factor was shown in Fig. 5 while Table 6 shows the ANOVA results obtained from the experimental data; the factors with highest F-value have highest contribution percentage on the yield. Based on Table 6, it is clear that all three factors make an equally important contribution to the yield from the Mizoroki-Heck coupling reaction. A comparison of the experimental and the predicted yield of the reaction have shown in fig 6 and the variation of the mean yield values against various extraction parameters shown in fig 7.

FIG. 5

TABLE 6

FIG. 6

FIG. 7

The surface plots shown in Fig. 8 helps to better display the effects of the experimental factors on the percentage yield. The effects of solvent and base, as shown in Fig. 8a, indicate that polar solvents such as DMF and DMF/Water were more efficient in increasing the yield of the products, to $88 \%$. However, the reactions in ethanol and water did not proceed even after prolonged stirring at reflux temperature, probably due to the low solubility of the complexes in this protic solvent. The effect of different mineral bases on this reaction was investigated by using the coupling of p-CHO-Ph-Cl with ethyl acrylate as a test case. $\mathrm{K}_{2} \mathrm{CO}_{3}$ and $\mathrm{K}_{3} \mathrm{PO}_{4}$ were the best choice of base and the yield of product could be increased to $88 \%$. The interaction surface plot of the catalyst loading (mol\%) and solvent, as shown in Fig. 8b indicate that the percentage yield is higher in DMF and DMF/Water, and with a catalyst loading (mol\%) of 0.005 . The 
effects of solvent, base and catalyst loading (mol \%), as shown in Fig. 6c, and confirm above results.

\section{FIG. 8}

\subsection{2 | Mizoroki-Heck coupling reaction of functionalized aryl chlorides}

Using the optimized reaction conditions, complexes $\mathbf{1}$ and $\mathbf{2}$ were applied in the reaction of various functionalized aryl chlorides bearing both electron-donating to electron-withdrawing groups with olefin. Aryl chlorides were converted into the corresponding coupled products in high to excellent yields (Table 7).

\section{TABLE 7}

A comparison between the catalytic activities of presented complexes and other Pd catalysts having different ancillary ligands in Suzuki-Miyaura reaction was carried out. The results indicated that the differences in catalytic behavior demonstrated in Table 8 should be ascribed not only to the differences in the experimental conditions (e.g. effects of solvent, base, and catalyst loading), but mainly attributed to the characteristic differences in the Pd content. The donor atoms of ligand have substantial effect on stabilization and consequently performance of Pd catalyst and the ligand-controlling conditions is clearly obvious in such catalytic reactions carried out under similar experimental conditions. Compound 2 seems to give the best results in accordance with Table 8.

TABLE 8 


\section{4 | Conclusions}

The present study describes the synthesis and characterization of new diphosphinium salt $\mathbf{S}$ diphosphine ylide $\mathbf{Y}^{\mathbf{1}}$ and complexes $\mathbf{1}$ and $\mathbf{2}$ derived from $\mathrm{PdBr}_{2} \mathrm{COD}$ and bifunctionalized phosphorus ylides $\left(\mathbf{Y}^{\mathbf{1}}\right.$ and $\mathbf{Y}^{\mathbf{2}}$ ) by simple and convenient synthetic methods in satisfactory yields. These compounds were characterized using FT-IR, and NMR $\left({ }^{1} \mathrm{H},{ }^{13} \mathrm{C}\right.$ and $\left.{ }^{31} \mathrm{P}\right)$ analyses as well as X-ray structural analyses. The catalytic activity of complexes $\mathbf{1}$ and $\mathbf{2}$ toward MizorokiHeck cross-coupling reaction has been investigated while the Taguchi method has been used to optimize the yield of the products of the Mizoroki-Heck coupling reaction. The results also indicate that utilization of the Taguchi method gives a suitable approach for optimization of the yield of the Mizoroki-Heck coupling. The effect of each factor was estimated using individual contributions as response functions. The results of ANOVA showed that the all factors (solvent, base and catalyst (mol\%) have significant effect on the yield and have highest $\mathrm{F}$ and high contribution percentage on the yield of Mizoroki-Heck coupling process.

\section{Acknowledgements}

Funding of our research from the Bu-Ali Sina University is gratefully acknowledged.

\section{Supplementary material}


Physical measurements and selected ${ }^{31} \mathrm{P},{ }^{13} \mathrm{C}$ and ${ }^{1} \mathrm{H}$ NMR spectra of some compounds can be found in the online version. CCDC 1431939 and 1812607 contains the supplementary crystallographic data for the complexes $\mathbf{1}$ and $\mathbf{2}$, respectively. These data can be obtained free of charge via www.ccdc.cam.ac.uk/data_request/cif or from the Cambridge Crystallographic Data Center, 12, Union Road, Cambridge CB2 1EZ, UK. Tel.: +44 01223 762911; or deposit@ccdc.cam.ac.uk.

\section{References}

[1] E.C. Spencer, M. B. Mariyatra, J.A.K. Howard, A.M. Kenwrigh, K.J. Panchanatheswaran, Organomet. Chem. 2007, 5, 1081.

[2] S.J. Sabounchei, M. Ahmadi, F. AkhlaghiBagherjeri, H.R. Khavasi, J. Chem. Sci. 2013, $3,653$.

[3] S.J. Sabounchei, A. Hashemi, A. Yousefi, P. Gohari Derakhshandeh, R. Karamian, M. Asadbegy, K. Van Hecke, Polyhedron. 2017, 135, 1.

[4] D. Aguilar, M.A. Aragues, R. Bielsa, E. Serrano, T. Soler, L.R. Navarro, E.P. Urriolabeitia, J. Organomet. Chem. 2008, 3, 417.

[5] A. Spannenberg, W. Baumann, U. Rosenthal, Organometallics. 2000, 19, 3991.

[6] S.J. Sabounchei, M. Hosseinzadeh, S. Salehzadeh, F. Maleki, R.W. Gable, inorg. chem. Front. 2017, 4, 2017.

[7] E.C. Spencer, B. Kalyanasundari, M. Baby Mariyatra, J. A.K. Howard, K. Panchanatheswaran, Inor.Chim. Acta. 2006, 359, 35-43 
[8] R.E. Cramer, S. Roth, F. Edelmann, M.A. Bruck, K.C. Cohn, J.W. Gilje, Organometallics. 1989, 8, 1192-1199.

[9] M.M. Ebrahim, H. Stoeckli-Evans, K. Panchanatheswaran, Polyhedron. 2007, 26, 34913495

[10] E.C. Spencer, M.B. Mariyatra, J.A.K. Howard, A.M. Kenwright, K. Panchanatheswaran, J. Organomet. Chem. 2007, 692, 1081-1086.

[11] S.J. Sabounchei, M. Panahimehr, M. Ahmadi, Z. Nasri, H. R. Khavasi, J. Organomet. Chem. 2013, 723, 207.

[12] S.J. Sabounchei, M. Panahimehr, M. Ahmadi, F. Akhlaghia, C. Boscovic, C. R. Chim. 2014, 17,81 .

[13] S.J. Sabounchei, M. Ahmadi, Z. Nasri, E. Shams, S. Salehzadeh, Y. Gholiee, R. Karamian, M. Asadbegy, S. Samiee, C. R. Chim. 2013, 16, 159.

[14] B.L. Shaw, S.D. Perera, Chem. Commun. 1998, 17, 1863.

[15] L.D. Deborah, D.K.B. Maarten, P.F. Gino, G.V. Johannes, W.N.M. Piet, C.J.K. Paul, Eur. J. Inorg. Chem. 2012, 10, 1660.

[16] A. Ghorbani-Choghamarani, A. Naghipour, H. Babaee, B. Notash, Polyhedron. 2016, $119,517-524$.

[17] S.J. Sabounchei, M Ahmadi, Catal. Commun. 2013, 37, 114.

[18] S. J. Sabounchei, A. Sedghi, A. Hashemi, M. Hosseinzadeh, M. Bayat, R.W. Gable, Appl. Organometal. Chem. 2017, 3850.

This article is protected by copyright. All rights reserved. 
[19] S. J. Sabounchei, Ali Hashemi, M. Hosseinzadeh, Sadegh Salehzadeh, Farahnaz Maleki, Catalysis Letters. 2017, 147, 2319-2331.

[20] H.Yuan Yen, J. Yan Li, J. Environm. Manag. 2015, 161, 344-349.

[21] D. Drew, J.R. Doyle, A.G. Shaver, Inorg. Synth. 1972, 13, 47.

[22] O.V. Dolomanov, L.J. Bourhis, R.W. Grosse-Kunstleve, P.D. Adams, R.J. Gildea, J.A.K. Howard and H. Puschmann, J. Appl. Cryst. 2011, 44, 1259-1263.

[23] G.M. Sheldrick, Acta. Cryst. A. 2015, C71, 3-8.

[24] G.M. Sheldrick, Acta. Cryst. 2015, A71, 3-8.

[25] M. Carbo, N. Marin, R. Navarro, T. Soler, E.P. Urriolabeitia, Eur. J. Inorg. Chem. 2006, 2006, 4629-4641.

[26] S.J. Sabounchei, S. Samiee, D. Nematollahi, A. Naghipour, D.M. Morales, Inorg. Chim. Acta. 2010, 363, 3973.

[27] P.J. Ross, McGraw-Hill, Singapore. 1996.

[28] M. A. Schoonen, J. M.T. Schoonen, J. Colloid and Inter. Sci. 2014, 422, 1-8.

[29] M.P. Elizalde-González, L.E. Garcia-Diaz, Chemi. Engin. J. 2010, 163, 55-61.

[30] J. Zolgharnein, N. Asanjarani, T. Shariatmanesh, International Biodeterioration \& Biodegradation. 2013, 85, 66-77.

[31] B. Ramavandi, G. Asgari, J. Faradmal,S. Sahebi and B. Roshani, Korean J. Chem. Eng. 2014, 31, 2207-2214.

This article is protected by copyright. All rights reserved. 
[32] S. Athreya1, Y.D.Venkatesh, International Refereed Journal of Engineering and Science (IRJES). 2012, 1,13-19

[33] C. S. Chou, R.Y. Yang, J. H. Chen and S.W. Chou, Powder Technol. 2010, 199, 264271.

[34] N. J. Cox, J. Warburton, A. Armstrong and V. J. Holliday, Earth Surf. Proc. Land. 2008, $33,25-39$

[35] K. R. Balinge, P. R.Bhagat, Comptes Rendus Chimie. 2017, 20, 773-804.

[36] X.-Jun Yu, R. Zhou, Y. Zhang, H.Yan Fu, R. Xiang Li, H. Chen, X. Jun Li, Catalysis Communication. 2010, 12, 222-225.

[37] D. A. Alonso, C. Na jera, M. C. Pacheco, Adv. Synth. Catal. 2002, 67 (16), 5588-5594

[38] T. Mino, Y. Shirae, Y.Sasai, M. Sakamoto, and T. Fujita, J. Org. Chem. 2006, 71, 68346839.

[39] S.J. Sabounchei, H. Nemattalab, H.R. Khavasi, X-Ray Struct. Anal. Online . 2010, 26, 35.

Table 1. Spectroscopic data for compounds $\mathbf{S}, \mathbf{Y}^{\mathbf{1}}, \mathbf{Y}^{2}, \mathbf{1}$ and $\mathbf{2}$.

\begin{tabular}{lllll}
\hline Compound & $\begin{array}{l}\mathrm{IR} ; v(\mathrm{CO}) \\
\mathrm{cm}^{-1}\end{array}$ & $\begin{array}{l}{ }^{1} \mathrm{H} \mathrm{NMR} ; \\
\delta(\mathrm{PCHor} \\
\left.\mathrm{PCH}_{2}\right) \mathrm{ppm}\end{array}$ & $\begin{array}{l}{ }^{13} \mathrm{C} \mathrm{NMR} ; \\
\delta(\mathrm{CO}) \mathrm{ppm}\end{array}$ & $\begin{array}{l}{ }^{31} \mathrm{P} \mathrm{NMR} ; \delta(\mathrm{PCH}) \\
\text { and }\left(\mathrm{PPh}_{2}\right) \mathrm{ppm}\end{array}$ \\
\hline $\mathbf{S}$ & 1669 & 6.06 & 191.9 & 26.76 \\
$\mathbf{Y}^{\mathbf{1}}$ & 1568 & 4.24 & 183.46 & 15.26 \\
$\mathbf{Y}^{\mathbf{2}}$ & 1571 & 4.08 & 183.36 & $14.45,-15.63$ \\
$\mathbf{1}$ & 1634 & 6.33 & 197.99 & $32.9,29.57$
\end{tabular}

This article is protected by copyright. All rights reserved. 
Table 2. Crystal data and structure refinement for $\mathbf{Y}^{\mathbf{1}}$ and $\mathbf{2}$.

\begin{tabular}{|c|c|c|}
\hline & Compound $\mathrm{Y}^{1}$ & Compound 2 \\
\hline Empirical formula & $\mathrm{C}_{42} \mathrm{H}_{34} \mathrm{O}_{2} \mathrm{P}_{2} \mathrm{Br}_{2}$ & $\mathrm{C}_{69} \mathrm{H}_{60.74} \mathrm{Br}_{6} \mathrm{Cl}_{2} \mathrm{O}_{2.37} \mathrm{P}_{4} \mathrm{Pd}_{2}$ \\
\hline Formula weight & 792.45 & 1814.83 \\
\hline$T[\mathrm{~K}]$ & $130.00(10)$ & $130.00(10)$ \\
\hline Crystal system & orthorhombic & monoclinic \\
\hline Space group & Pbca & $\mathrm{P} 2{ }_{1} / \mathrm{c}$ \\
\hline$a[\AA]$ & $15.72121(12)$ & $21.2364(2)$ \\
\hline$b[\AA]$ & $8.79483(9)$ & $19.1159(2)$ \\
\hline$c[\AA]$ & $25.5658(2)$ & $16.81993(16)$ \\
\hline$\alpha\left[^{\circ}\right]$ & 90 & 90 \\
\hline$\beta\left[^{\circ}\right]$ & 90 & $99.6027(10)$ \\
\hline$\gamma\left[^{\circ}\right]$ & 90 & 90 \\
\hline$V\left[\AA^{3}\right]$ & $3534.86(6)$ & $6732.43(13)$ \\
\hline$Z$ & 4 & 4 \\
\hline$\rho_{\text {calc }} \mathrm{g} / \mathrm{cm}^{3}$ & 1.489 & 1.790 \\
\hline$\mu\left[\mathrm{mm}^{-1}\right]$ & 4.047 & 10.467 \\
\hline $\mathrm{F}(000)$ & 1608.0 & 3558.7 \\
\hline $2 \theta$ range $\left[{ }^{\circ}\right]$ & 6.91 to 154.23 & 7.056 to 154.232 \\
\hline Index ranges & $\begin{array}{l}-11 \leq \mathrm{h} \leq 19,-11 \leq \mathrm{k} \leq 10 \\
-31 \leq 1 \leq 32\end{array}$ & $\begin{array}{l}-26 \leq \mathrm{h} \leq 23,-18 \leq \mathrm{k} \leq 24,- \\
20 \leq 1 \leq 21\end{array}$ \\
\hline Independent reflections & $\begin{array}{l}3733\left[\mathrm{R}_{\text {int }}=0.0282,\right. \\
\left.\mathrm{R}_{\text {sigma }}=0.0121\right]\end{array}$ & $\begin{array}{l}14063\left[R_{\text {int }}=0.0437, R_{\text {sigma }}=\right. \\
0.0370]\end{array}$ \\
\hline
\end{tabular}



Data/restr./param.
$3733 / 0 / 218$
$14063 / 4 / 782$
Goodness-of-fit on $\mathrm{F}^{2}$
1.031
1.055
$\mathrm{R}_{1} / \mathrm{wR}_{2}[I>2 \sigma(I)]$
$\mathrm{R}_{1}=0.0286, \mathrm{wR}_{2}=0.0710$
$\mathrm{R}_{1}=0.0452, \mathrm{wR}_{2}=0.1242$

Table 3 Selected bond lengths [ $[\AA]$ and bond angles $\left[{ }^{\circ}\right]$ for $\mathbf{Y}^{\mathbf{1}}$ and $\mathbf{2}$.

\begin{tabular}{|c|c|c|c|c|c|}
\hline \multirow{2}{*}{\multicolumn{2}{|c|}{ Compound $\mathbf{Y}^{\mathbf{1}}$}} & \multicolumn{4}{|l|}{ Compound 2} \\
\hline & & \multirow[t]{2}{*}{ Mol 1} & \multicolumn{2}{|c|}{ Mol 2} & \\
\hline \multicolumn{5}{|c|}{ Bond distances } & \\
\hline $\mathrm{Br}_{1}-\mathrm{C}_{5}$ & $1.9042(19)$ & $\mathrm{Pd}_{1}-\mathrm{Br}_{1}$ & $2.4796(5)$ & $\mathrm{Pd}_{2}-\mathrm{Br}_{4}$ & $2.4675(5)$ \\
\hline $\mathrm{O}_{1}-\mathrm{C}_{2}$ & $1.260(2)$ & $\mathrm{Pd}_{1}-\mathrm{Br}_{2}$ & $2.5056(5)$ & $\mathrm{Pd}_{2}-\mathrm{Br}_{5}$ & $2.4923(5)$ \\
\hline $\mathrm{C}_{1}-\mathrm{C}_{2}$ & $1.396(2)$ & $\mathrm{Pd}_{1}-\mathrm{P}_{1}$ & $2.2321(10)$ & $\mathrm{Pd}_{2}-\mathrm{P}_{3}$ & $2.2500(10)$ \\
\hline $\mathrm{P}_{1}-\mathrm{C}_{1}$ & $1.7203(15)$ & $\mathrm{Pd}_{1}-\mathrm{C}_{1}$ & $2.139(4)$ & $\mathrm{Pd}_{2}-\mathrm{C}_{35}$ & $2.122(4)$ \\
\hline $\mathrm{P}_{1}-\mathrm{C}_{9}$ & $1.8148(16)$ & $\mathrm{O}_{1}-\mathrm{C}_{2}$ & $1.227(6)$ & $\mathrm{O}_{2}-\mathrm{C}_{36}$ & $1.228(5)$ \\
\hline $\mathrm{P}_{1}-\mathrm{C}_{10}$ & $1.8071(16)$ & $\mathrm{C}_{1}-\mathrm{C}_{2}$ & $1.497(6)$ & $\mathrm{C}_{35}-\mathrm{C}_{36}$ & $1.485(6)$ \\
\hline $\mathrm{P}_{1}-\mathrm{C}_{16}$ & $1.8090(16)$ & $\mathrm{P}_{2}-\mathrm{C}_{21}$ & $1.806(4)$ & $\mathrm{P}_{4}-\mathrm{C}_{55}$ & $1.806(4)$ \\
\hline $\mathrm{C}_{9}-\mathrm{C}_{9 \mathrm{i}}$ & $1.528(3)$ & $\mathrm{P}_{1}-\mathrm{C}_{29}$ & $1.795(4)$ & $\mathrm{P}_{3}-\mathrm{C}_{63}$ & $1.808(4)$ \\
\hline \multicolumn{6}{|c|}{ Bond angles } \\
\hline $\mathrm{C}_{1}-\mathrm{P}_{1}-\mathrm{C}_{9}$ & $113.41(7)$ & $\mathrm{Br}_{2}-\mathrm{Pd}_{1}-\mathrm{Br}_{1}$ & $90.076(17)$ & $\mathrm{Br}_{4}-\mathrm{Pd}_{2}-\mathrm{Br}_{5}$ & $90.640(16)$ \\
\hline $\mathrm{C}_{2}-\mathrm{C}_{1}-\mathrm{P}_{1}$ & $114.90(12)$ & $\mathrm{C}_{1}-\mathrm{Pd}_{1}-\mathrm{P}_{1}$ & $95.88(11)$ & $\mathrm{C}_{35}-\mathrm{Pd}_{2}-\mathrm{P}_{3}$ & $93.76(11)$ \\
\hline $\mathrm{O}_{1}-\mathrm{C}_{2}-\mathrm{C}_{1}$ & $122.17(15)$ & $\mathrm{C}_{1}-\mathrm{Pd}_{1}-\mathrm{Br}_{1}$ & $167.42(12)$ & $\mathrm{C}_{35}-\mathrm{Pd}_{2}-\mathrm{Br}_{4}$ & $171.44(11)$ \\
\hline $\mathrm{C}_{4}-\mathrm{C}_{5}-\mathrm{Br}_{1}$ & $117.95(14)$ & $\mathrm{P}_{1}-\mathrm{Pd}_{1}-\mathrm{Br}_{1}$ & $86.57(3)$ & $\mathrm{P}_{3}-\mathrm{Pd}_{2}-\mathrm{Br}_{4}$ & $87.78(3)$ \\
\hline $\mathrm{P}_{1}-\mathrm{C}_{9}-\mathrm{C}_{9 \mathrm{i}}$ & $111.25(14)$ & $\mathrm{P}_{1}-\mathrm{Pd}_{1}-\mathrm{Br}_{2}$ & $166.06(3)$ & $\mathrm{P}_{3}-\mathrm{Pd}_{2}-\mathrm{Br}_{5}$ & $175.27(3)$ \\
\hline
\end{tabular}

Symmetry Code: i 1-x,1-y,1-z

Table 4 Controllable factors and their levels.

\begin{tabular}{llllll}
\hline Factor & Description & Level 1 & Level 2 & Level 3 & Level 4 \\
\hline B & Base & $\mathrm{K}_{2} \mathrm{CO}_{3}$ & $\mathrm{~K}_{3} \mathrm{PO}_{4}$ & NaOAC & $\mathrm{NEt}_{3}$
\end{tabular}

This article is protected by copyright. All rights reserved. 


$\begin{array}{llllll}\text { S } & \text { Solvent } & \text { DMF } & \text { DMF/Water } & \text { Ethanol } & \text { Water } \\ \text { C } & \text { Catalyst }(\text { mol \%) } & 0.01 & 0.001 & 0.005 & 0.0005\end{array}$

Table $5 \mathrm{~L}_{16}$ orthogonal array and experimental results.

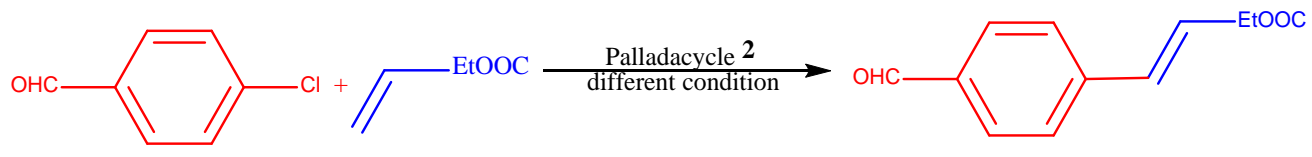

\begin{tabular}{|c|c|c|c|c|c|}
\hline \multirow[b]{2}{*}{ Run } & \multicolumn{3}{|c|}{ Factor } & \multirow[t]{2}{*}{ Yield (\%) } & \multirow[t]{2}{*}{$\mathrm{S} / \mathrm{N}$ ratio } \\
\hline & B & $S$ & $\mathrm{C}$ & & \\
\hline
\end{tabular}




\begin{tabular}{|c|c|c|c|c|c|}
\hline 1 & $\mathrm{~K}_{2} \mathrm{CO}_{3}$ & $\mathrm{DMF}$ & 0.0050 & 88 & 38.8897 \\
\hline 2 & $\mathrm{~K}_{3} \mathrm{PO}_{4}$ & DMF & 0.0100 & 73 & 37.2665 \\
\hline 3 & $\mathrm{NaOAC}$ & $\mathrm{DMF}$ & 0.0010 & 60 & 35.5630 \\
\hline 4 & $\mathrm{NEt}_{3}$ & $\mathrm{DMF}$ & 0.0005 & 43 & 32.6694 \\
\hline 5 & $\mathrm{~K}_{2} \mathrm{CO}_{3}$ & DMF/Water & 0.0010 & 68 & 36.6502 \\
\hline 6 & $\mathrm{~K}_{3} \mathrm{PO}_{4}$ & DMF/Water & 0.0005 & 63 & 35.9868 \\
\hline 7 & $\mathrm{NaOAC}$ & DMF/Water & 0.0050 & 60 & 35.5630 \\
\hline 8 & $\mathrm{NEt}_{3}$ & DMF/Water & 0.0100 & 53 & 34.4855 \\
\hline 9 & $\mathrm{~K}_{2} \mathrm{CO}_{3}$ & Ethanol & 0.0005 & 55 & 34.8073 \\
\hline 10 & $\mathrm{~K}_{3} \mathrm{PO}_{4}$ & Ethanol & 0.0010 & 50 & 33.9794 \\
\hline 11 & $\mathrm{NaOAC}$ & Ethanol & 0.0100 & 67 & 36.5215 \\
\hline 12 & $\mathrm{NEt}_{3}$ & Ethanol & 0.0050 & 60 & 35.5630 \\
\hline 13 & $\mathrm{~K}_{2} \mathrm{CO}_{3}$ & Water & 0.0100 & 53 & 34.4855 \\
\hline 14 & $\mathrm{~K}_{3} \mathrm{PO}_{4}$ & Water & 0.0050 & 58 & 35.2686 \\
\hline 15 & $\mathrm{NaOAC}$ & Water & 0.0005 & 45 & 33.0643 \\
\hline 16 & $\mathrm{NEt}_{3}$ & Water & 0.0010 & 48 & 33.6248 \\
\hline
\end{tabular}

Table 6. Results of the analysis of variance (ANOVA)

This article is protected by copyright. All rights reserved. 


\begin{tabular}{lllllll}
\hline Source & DF $^{\mathrm{a}}$ & Seq. SS $^{\mathrm{b}}$ & Adj. SS $^{\mathrm{c}}$ & Adj. MS $^{\mathrm{d}}$ & $\mathrm{F}^{\mathrm{e}}$ & $\rho(\%)$ \\
\hline $\mathrm{S}$ & 3 & 472 & 472 & 157.333 & $*$ & 24.28 \\
$\mathrm{~B}$ & 3 & 472 & 472 & 157.333 & $*$ & 24.28 \\
$\mathrm{C}$ & 3 & 500 & 500 & 166.667 & $*$ & 25.72 \\
Error & 3 & 0 & 0 & 0.000 & & \\
Total & 15 & 1944 & & & & \\
\hline
\end{tabular}

${ }^{\mathrm{a}} \mathrm{DF}$ : degree of freedom.

${ }^{\mathrm{b}}$ Seq.SS: sequential sum of squares.

${ }^{\mathrm{c}}$ Adj.SS: adjusted sum of squares.

${ }^{\mathrm{d}}$ Adj.MS: adjusted mean of squares

${ }^{\mathrm{e}} \mathrm{F}$ : variance ratio 
Table 7. Mizoroki-Heck coupling reaction of aryl chlorides catalyzed by complexes $\mathbf{1}$ and $\mathbf{2}^{\mathrm{a}}$

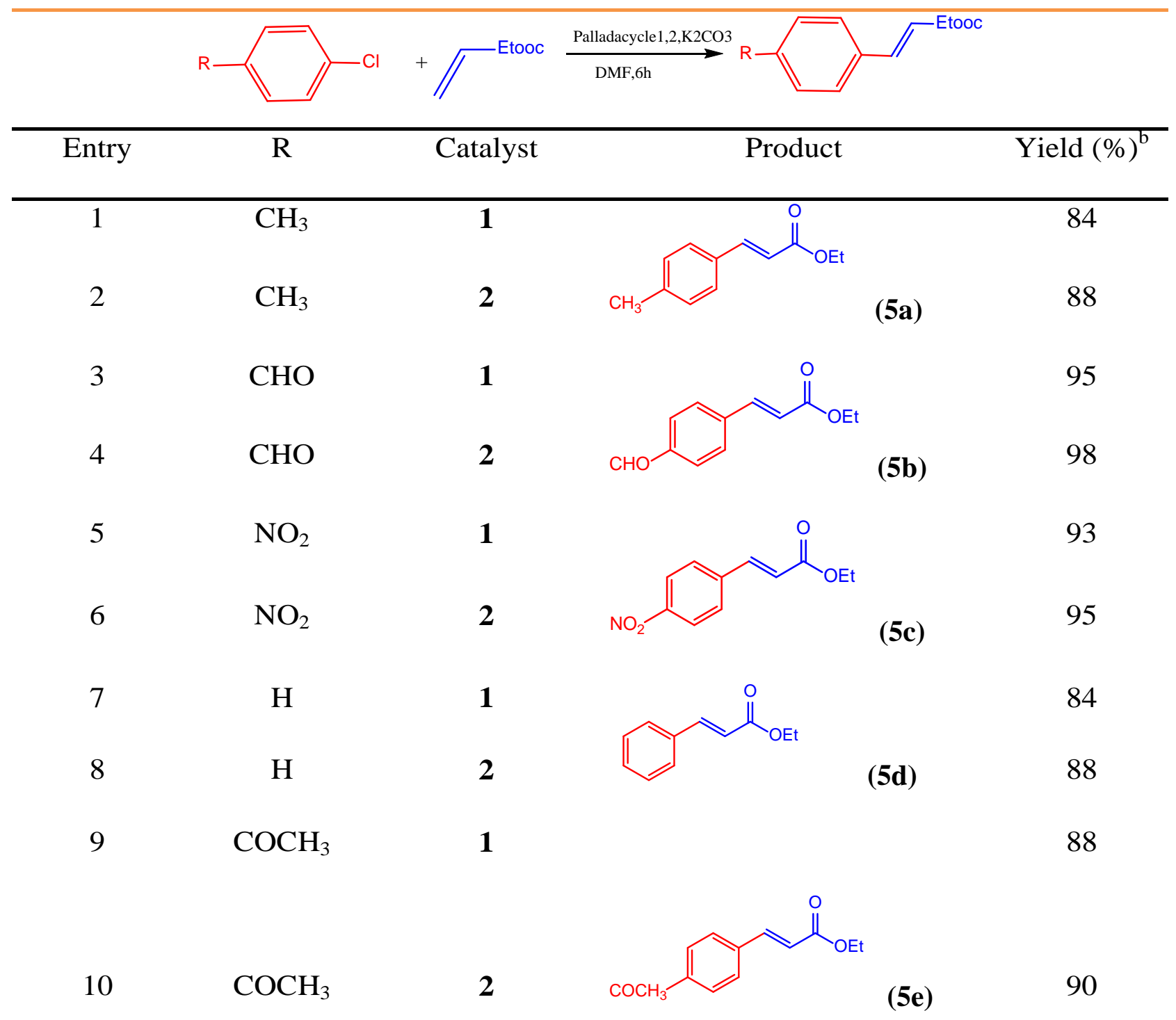

This article is protected by copyright. All rights reserved. 
${ }^{\mathrm{a}}$ Reaction conditions for Mizoroki-Heck coupling reaction: aryl chloride $(0.5 \mathrm{mmol})$, olefin $(0.75 \mathrm{mmol}), \mathrm{K}_{2} \mathrm{CO}_{3}(1$ mmol), DMF (2 ml), catalyst 1 and 2 (0.005 mmol), in air.

${ }^{\mathrm{b}}$ Isolated yield.

Table 8. Comparison of Mizoroki-Heck coupling reaction of $p$-nitrochlorobenzene and ethyl acrylate using palladacycle $\mathbf{2}$ and other catalytic system.

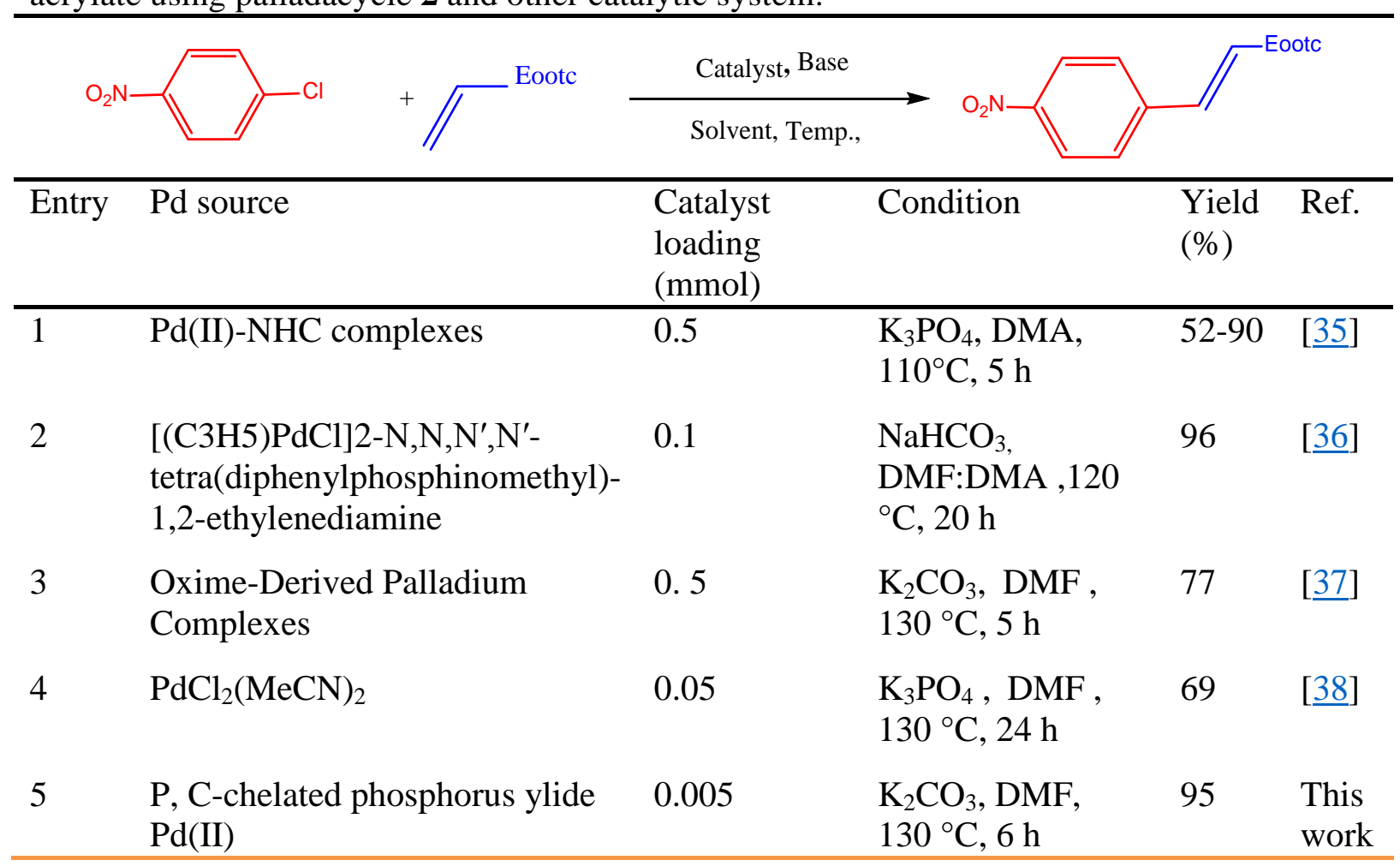




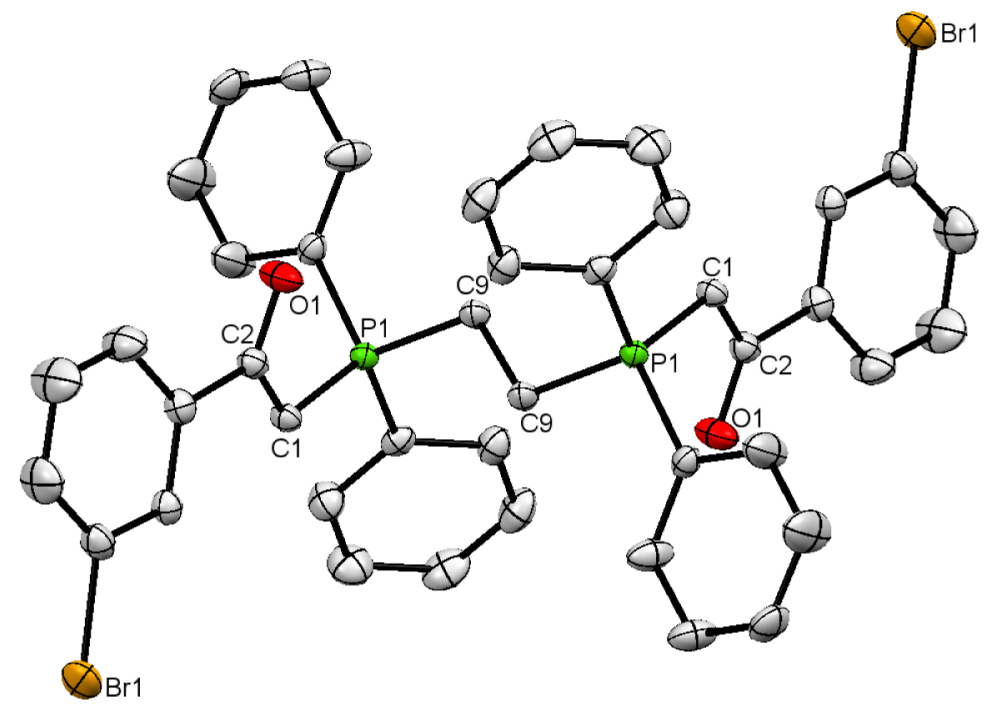

AOC_4882_F1.tif

This article is protected by copyright. All rights reserved. 


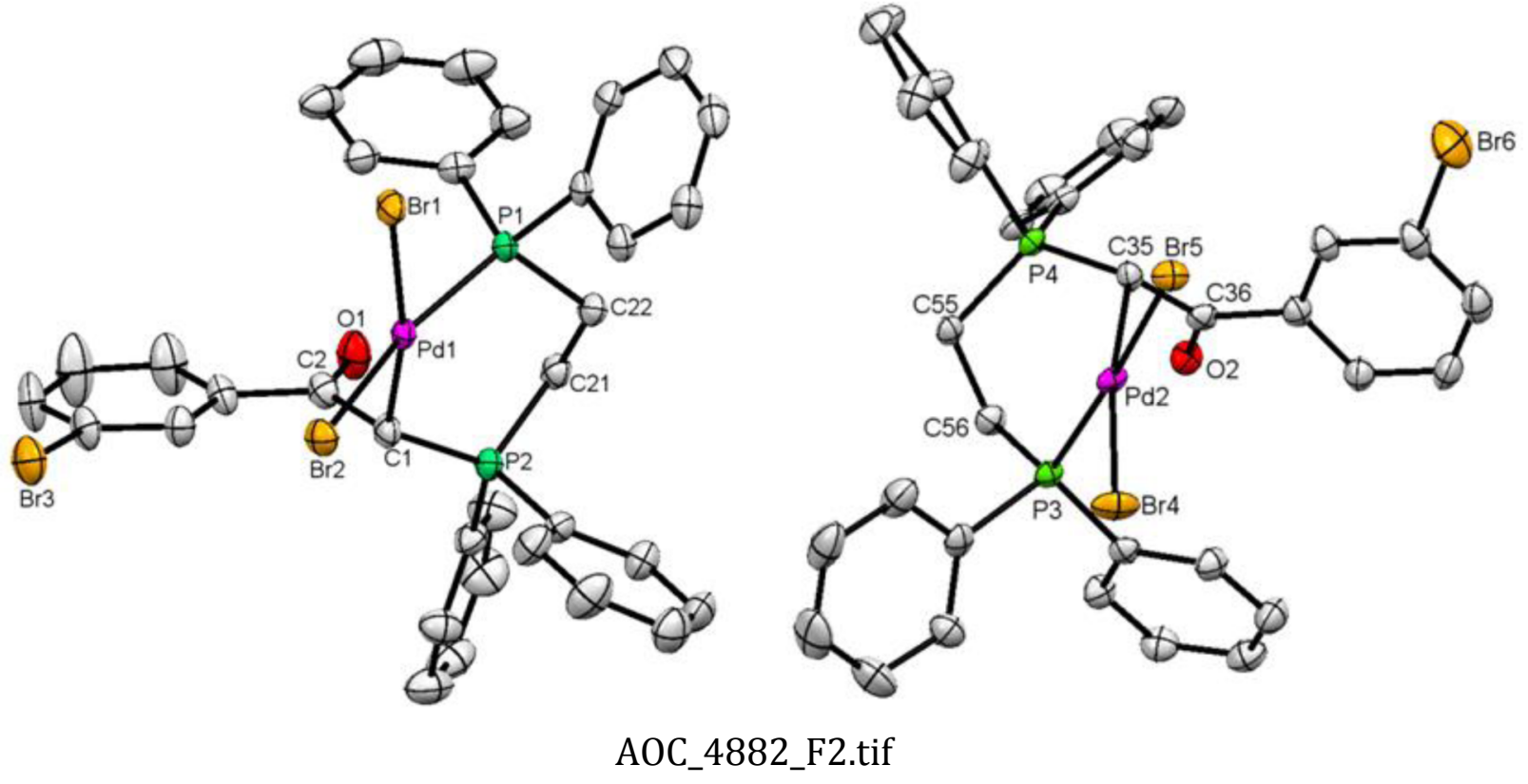

This article is protected by copyright. All rights reserved. 


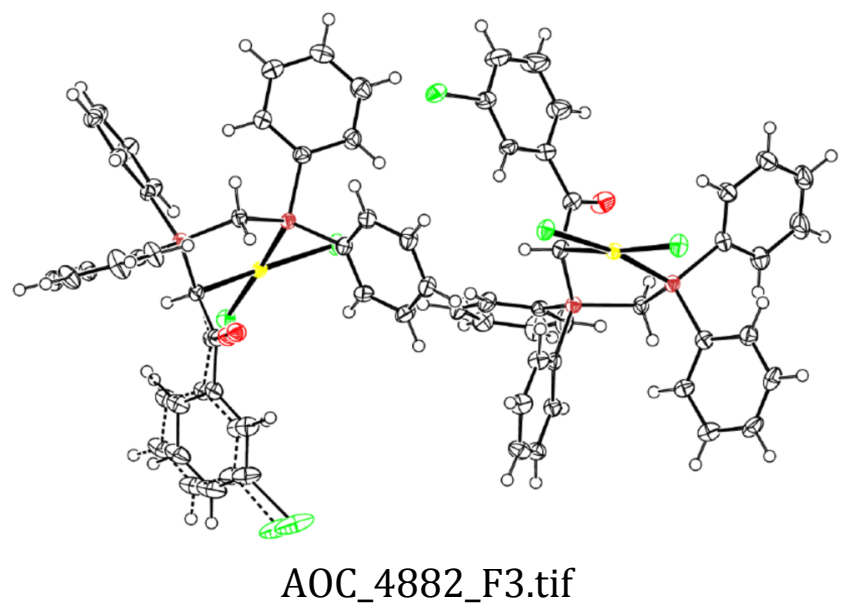

This article is protected by copyright. All rights reserved. 

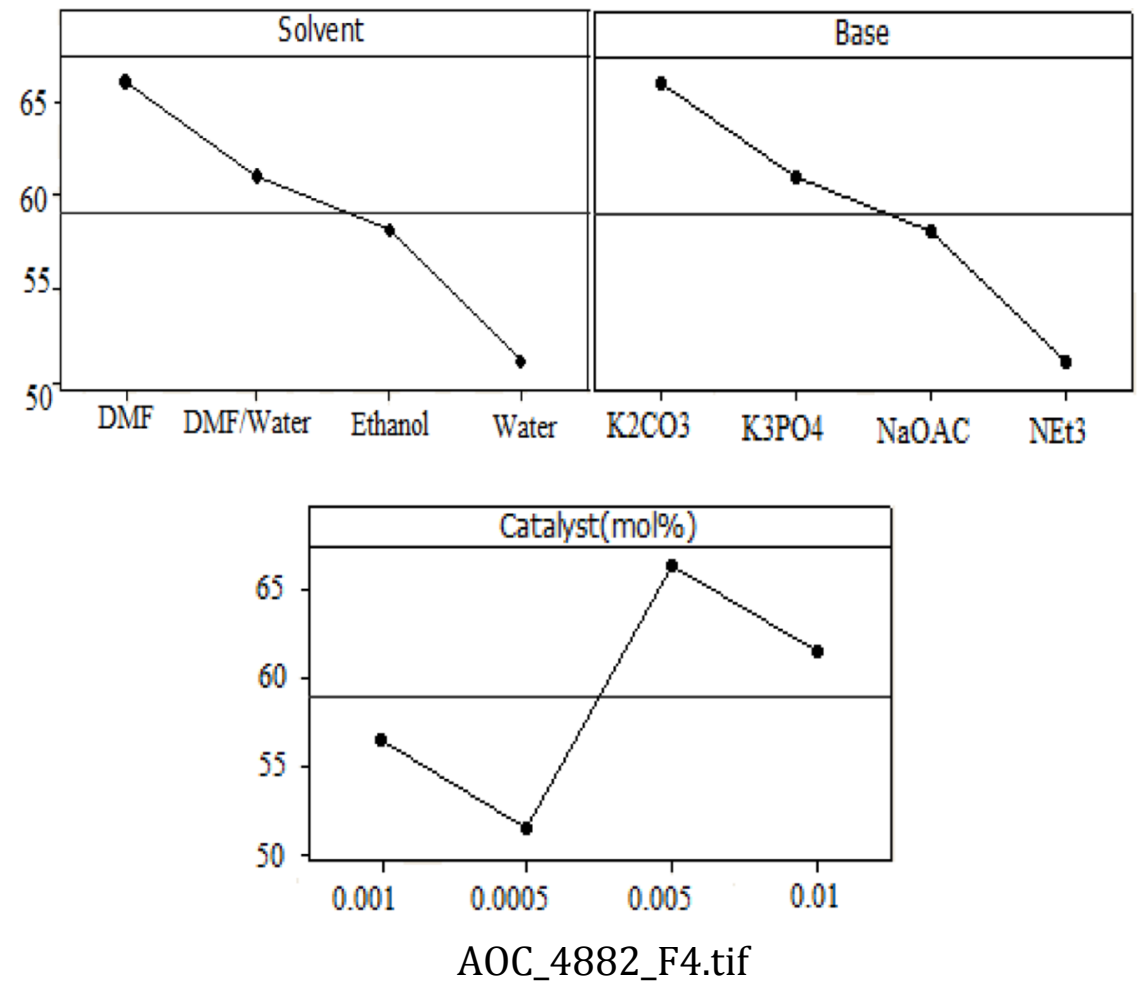

This article is protected by copyright. All rights reserved. 


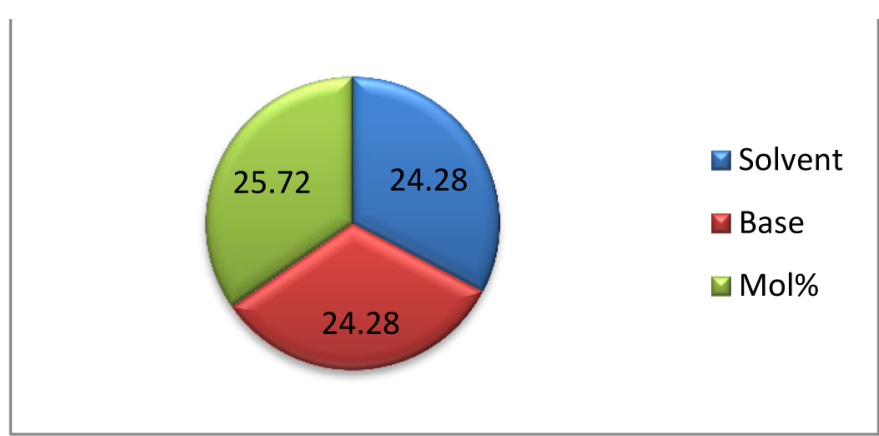

A0C_4882_F5.tif

This article is protected by copyright. All rights reserved. 


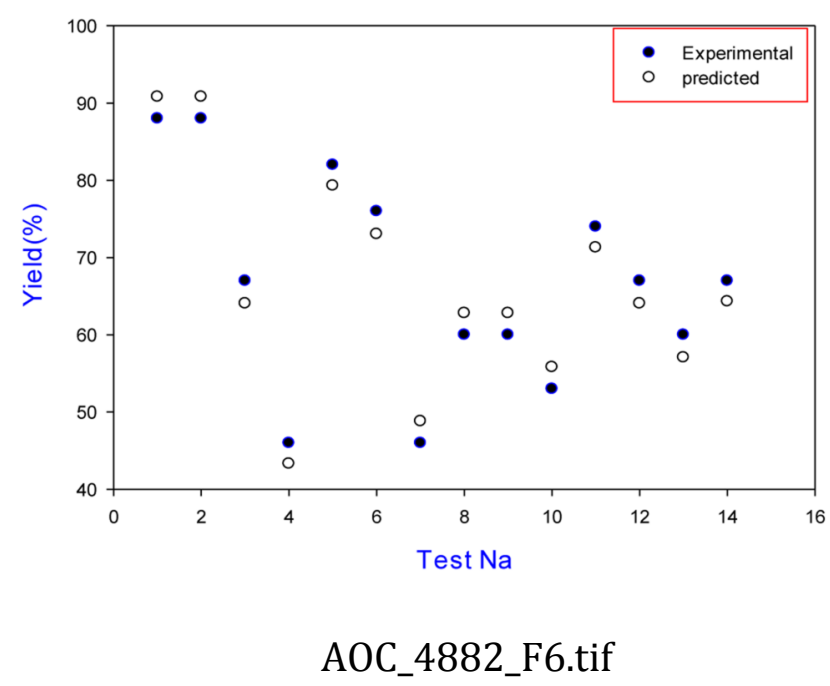

This article is protected by copyright. All rights reserved. 


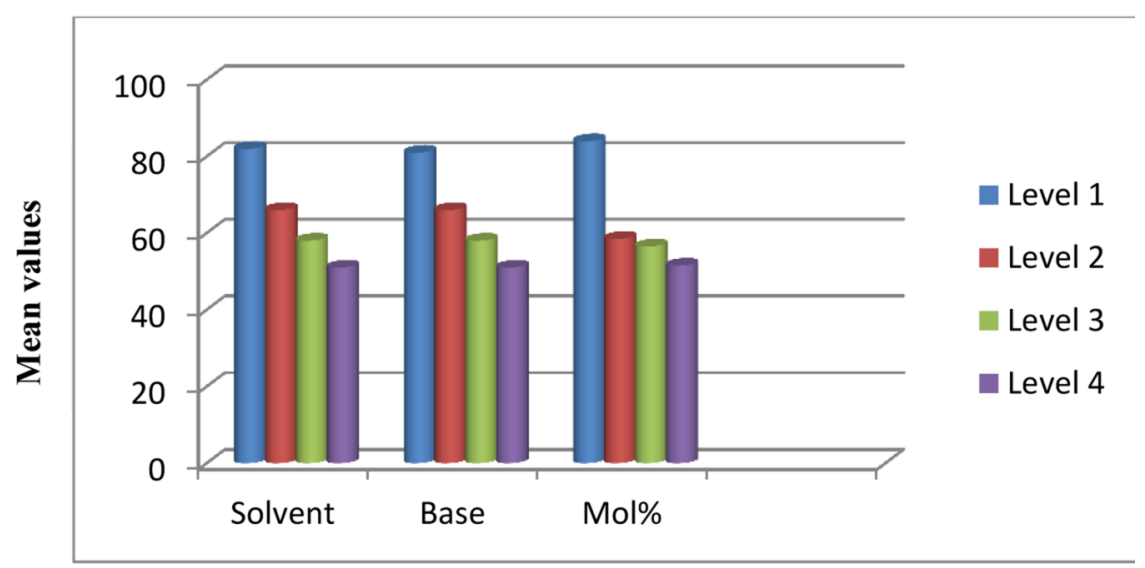

AOC_4882_F7.tif

This article is protected by copyright. All rights reserved. 

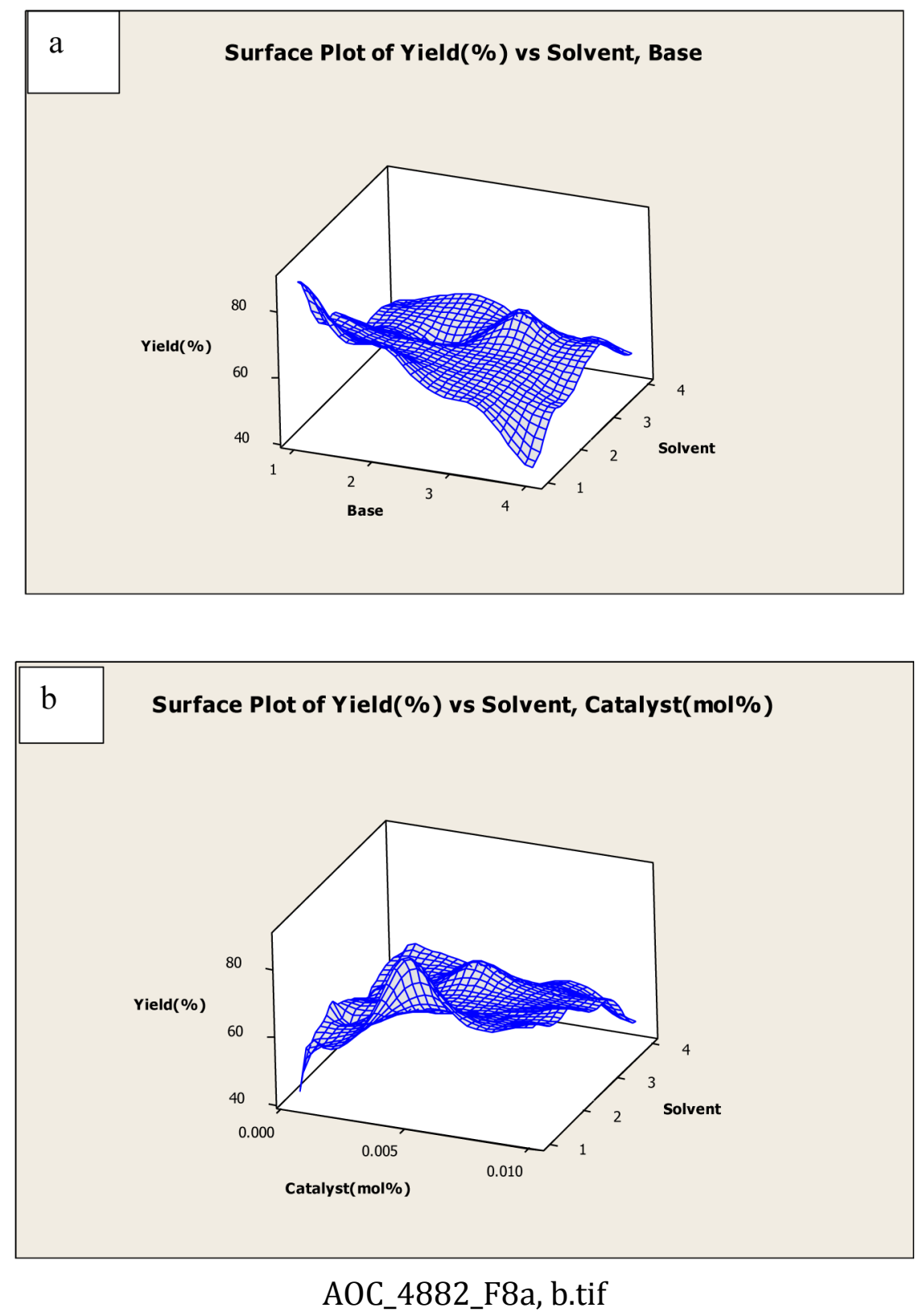

This article is protected by copyright. All rights reserved. 


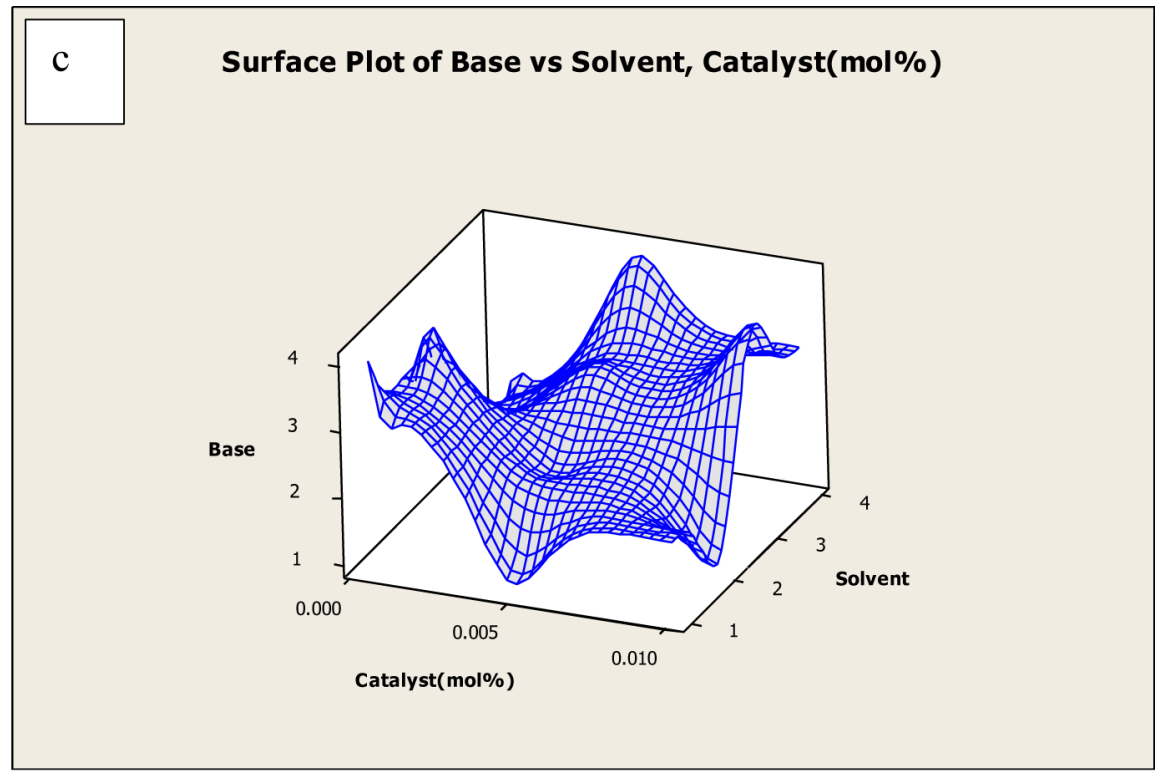

AOC_4882_F8c.tif

This article is protected by copyright. All rights reserved. 
Fig. 1. ORTEP view of X-ray crystal structure $\mathrm{Y} 1$.

Fig. 2. ORTEP view of X-ray crystal structure of molecules 1 and 2.

Fig. 3. Intramolecular interaction between of the molecules 2-1 and 2-2.

Fig. 4. Main effect of each factor by $\mathrm{S} / \mathrm{N}$ ratios

Fig. 5. Contribution percentage of factors for yield of Suzuki coupling reaction

Fig. 6. Comparison of experimental and predicted yield of reaction.

Fig. 7. The response graph illustrats the variation of the mean yield values plotted against various extraction parameters.

Fig. 8. Response surface plots for the interaction between factors.

SCHEME 1 tif. The possible coordination modes of phosphine ligands

SCHEME 2 tif. Synthesis of palladacycle complexes 1, 2 .

This article is protected by copyright. All rights reserved. 


\title{
Spectral and crystallography studies of new palladacycle complexes with $P, C$ - and C,C-donor ligands; Application of (OAL16) to optimizing the yield of Mizoroki-Heck reaction
}

\author{
Seyyed Javad Sabounchei ${ }^{1} \mid$ Khadijeh Badpa $^{1} \mid$ Ali Hashemi $^{1} \mid$ faezeh moniriyan ${ }^{1} \mid$ Robert W. \\ Gable $^{2}$ \\ ${ }^{1}$ Faculty of Chemistry, Bu-Ali Sina University, Hamedan, 65174, Iran. \\ ${ }^{2}$ School of Chemistry, University of Melbourne, Victoria, 3010, Australia. \\ *Corresponding author: jsabounchei@yahoo.co.uk (S.J. Sabounchei), Tel.: +98 8138272072.
}

\section{Graphical Abstract}

The new Pd complexes, C,C- and P,C-coordinated were characterized using FT-IR, NMR $\left({ }^{1} \mathrm{H}\right.$, ${ }^{13} \mathrm{C}$ and ${ }^{31} \mathrm{P}$ ) spectroscopic methods and X-ray. Also, a Taguchi method (L16) design was applied to optimize the yield of Mizoroki-Heck coupling reactions.

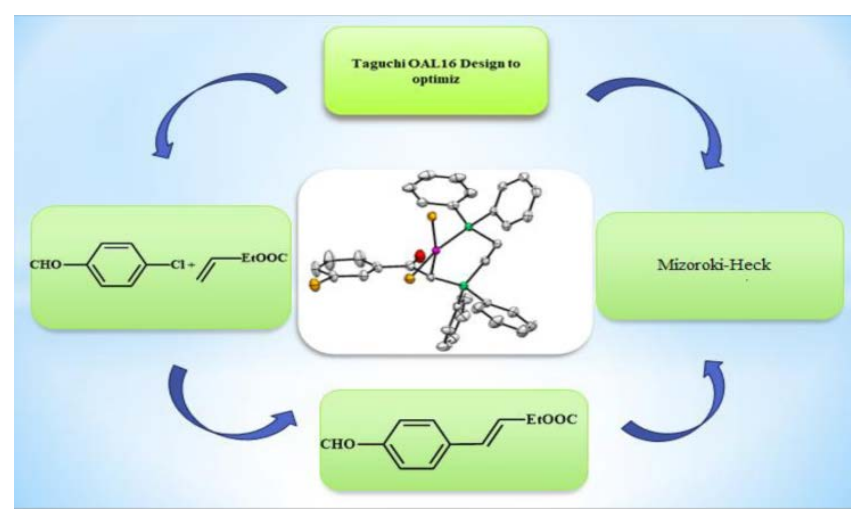

This article is protected by copyright. All rights reserved. 

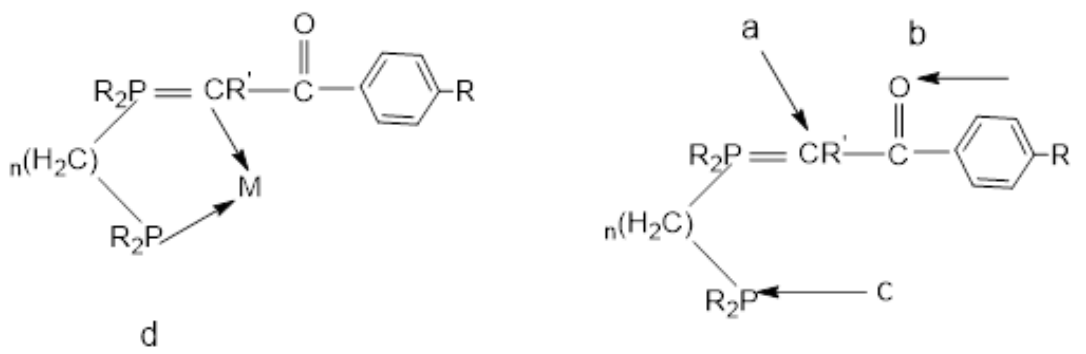

AOC_4882_SCHEME1.tif

This article is protected by copyright. All rights reserved. 

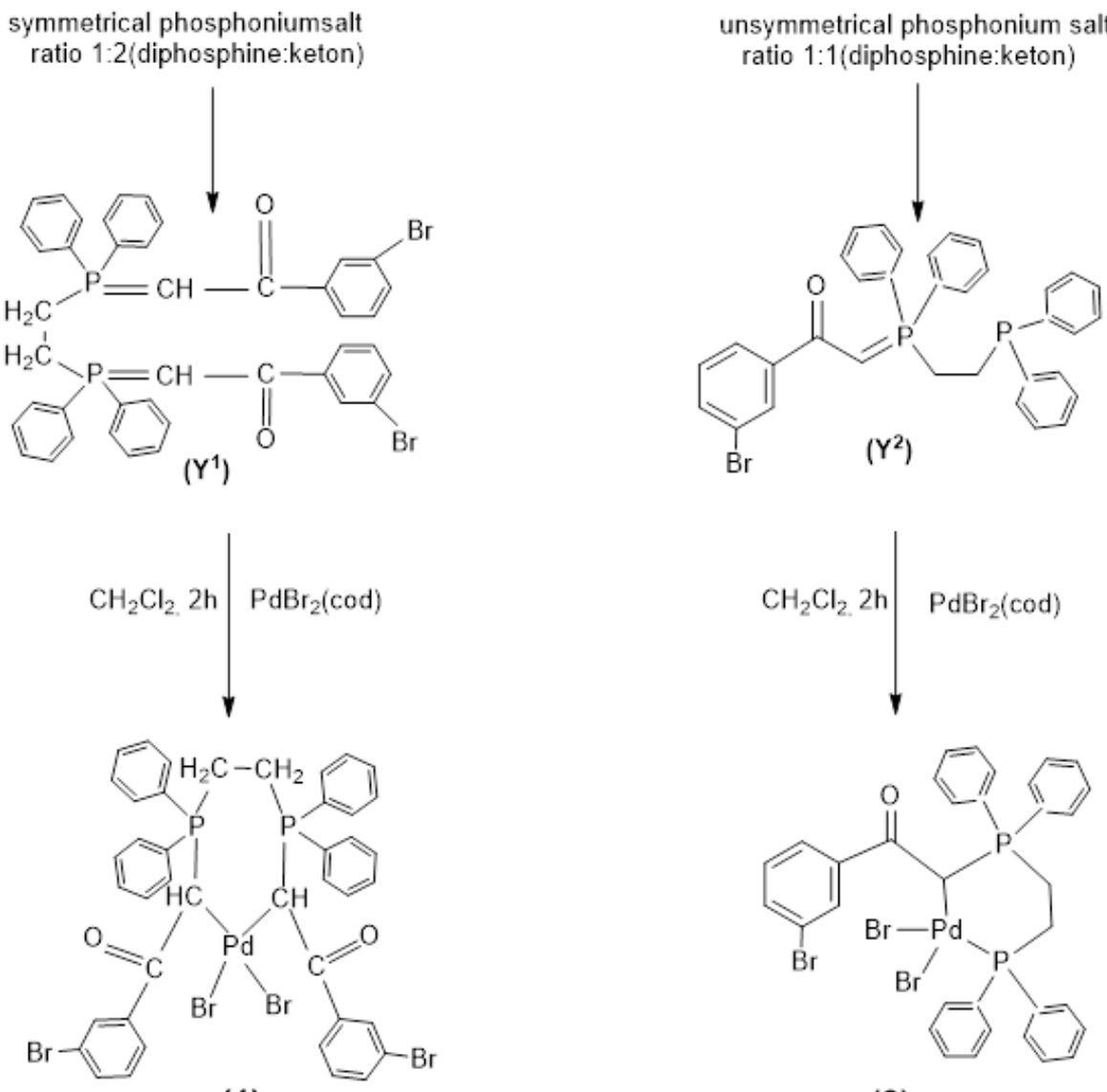

(1)

(2)

AOC_4882_SCHEME2.tif

This article is protected by copyright. All rights reserved. 


\section{University Library}

\section{- M I N E R VA}

\section{A gateway to Melbourne's research publications}

Minerva Access is the Institutional Repository of The University of Melbourne

Author/s:

Sabounchei, SJ;Badpa, K;Hashemi, A;Moniriyan, F;Gable, RW

Title:

Spectral and crystallography studies of new palladacycle complexes with P,C- and C,Cdonor ligands; Application of (OAL16) to optimizing the yield of Mizoroki-Heck reaction

Date:

2019-05-01

\section{Citation:}

Sabounchei, S. J., Badpa, K., Hashemi, A., Moniriyan, F. \& Gable, R. W. (2019). Spectral and crystallography studies of new palladacycle complexes with P,C- and C,C-donor ligands; Application of (OAL16) to optimizing the yield of Mizoroki-Heck reaction. APPLIED ORGANOMETALLIC CHEMISTRY, 33 (5), https://doi.org/10.1002/aoc.4882.

Persistent Link:

http://hdl.handle.net/11343/285553 